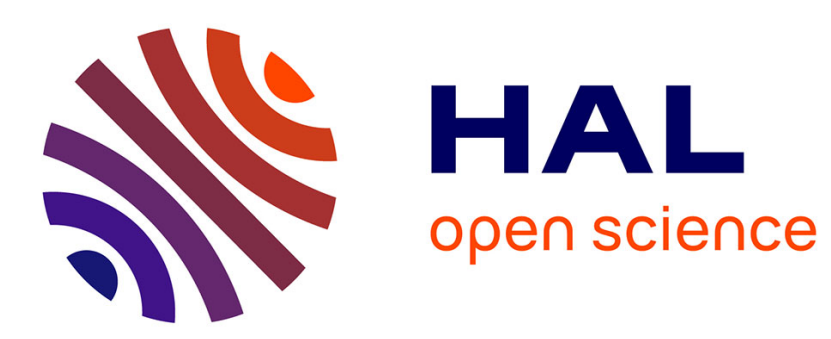

\title{
Genetic models of focal epilepsies
}

Morgane Boillot, Stéphanie Baulac

\section{To cite this version:}

Morgane Boillot, Stéphanie Baulac. Genetic models of focal epilepsies. Journal of Neuroscience Methods, 2015, 260, pp.132-143. 10.1016/j.jneumeth.2015.06.003 . hal-01166902

\section{HAL Id: hal-01166902 https://hal.sorbonne-universite.fr/hal-01166902}

Submitted on 23 Jun 2015

HAL is a multi-disciplinary open access archive for the deposit and dissemination of scientific research documents, whether they are published or not. The documents may come from teaching and research institutions in France or abroad, or from public or private research centers.
L'archive ouverte pluridisciplinaire HAL, est destinée au dépôt et à la diffusion de documents scientifiques de niveau recherche, publiés ou non, émanant des établissements d'enseignement et de recherche français ou étrangers, des laboratoires publics ou privés. 
26 pages, 4 tables, review article

\section{Genetic models of focal epilepsies}

Morgane Boillot ${ }^{a, b, c, d}$ and Stéphanie Baulac $c^{a, b, c, d}$

a INSERM, U 1127, ICM, F-75013, Paris, France; ${ }^{\mathrm{b}}$ CNRS, UMR 7225, ICM, F-75013, Paris, France; ${ }^{c}$

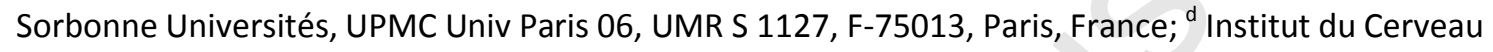
et de la Moelle épinière, ICM, F-75013, Paris, France.

Corresponding author: Dr. Stéphanie Baulac, Institut du Cerveau et de la Moelle (ICM), Hôpital de la Pitié-Salpêtrière, 47 bd de l’hôpital, Paris F-75013, France. Tel: +331-5727-4339; Fax: +331-5727-

4339; Email: stephanie.baulac@upmc.fr 


\section{Highlights}

- Several focal epilepsy syndromes are proven to be monogenic disorders.

- Mutations in CHRNA4, CHRNB2, CHRNA2 and KCNT1 cause autosomal dominant nocturnal frontal lobe epilepsy (ADNFLE).

- Mutations in LGI1 cause autosomal dominant epilepsy with auditory features (ADEAF).

- This review provides an update of the mutational spectrum in these genes.

- We review cellular and genetic animal models generated for autosomal dominant focal epilepsies.

\section{ABSTRACT}

Focal epilepsies were for a long time thought to be acquired disorders secondary to cerebral lesions. However, the important role of genetic factors in focal epilepsies is now well established. Several focal epilepsy syndromes are now proven to be monogenic disorders. While earlier genetic studies suggested a strong contribution of ion channel and neurotransmitter receptor genes, later work has revealed alternative pathways, among which the mammalian target of rapamycin (mTOR) signal transduction pathway with DEPDC5. In this article, we provide an update on the mutational spectrum of neuronal nicotinic acetylcholine receptor genes (CHRNA4, CHRNB2, CHRNA2) and KCNT1 causing autosomal dominant nocturnal frontal lobe epilepsy (ADNFLE), and of LGII in autosomal dominant epilepsy with auditory features (ADEAF). We also emphasize, through a review of the current literature, the contribution of in vitro and in vivo models developed to unveil the pathogenic mechanisms underlying these two epileptic syndromes.

\section{KEYWORDS}

genetic focal epilepsies, cellular and animal models, CHRNA4, CHRNB2, KCNT1, LGI1, DEPDC5 


\section{ABBREVIATIONS}

$\mathrm{ACh}=$ acetylcholine

ADEAF = autosomal dominant epilepsy with auditory features ADNFLE = autosomal dominant nocturnal frontal lobe epilepsy

CHRNA4, CHRNB2, CHRNA2 $=\alpha 4, \beta 2$ and $\alpha 2$ subunits of nicotinic acetylcholine receptors $\mathrm{KCNT} 1$ = potassium channel, subfamily $\mathrm{T}$, member 1

LGI1 = leucine-rich, glioma inactivated 1

$\mathrm{nAChR}=$ nicotinic acetylcholine receptor 


\section{INTRODUCTION}

Twenty years have now passed since the first identification of a mutated gene in inherited focal epilepsies. In 1995, a mutation in CHRNA4, encoding the a4 subunit of the nicotinic acetylcholine receptor (nAChR), was identified in autosomal dominant nocturnal frontal lobe epilepsy (ADNFLE) (Steinlein et al., 1995). Subsequently, mutations in CHRNB2 and CHRNA2, encoding respectively the $\beta 2$ and $\alpha 2$ subunits of nAChRs, were reported in a subset of ADNFLE families (Aridon et al., 2006; De Fusco et al., 2000), reinforcing the commonly held view that monogenic focal epilepsies belonged to the channelopathies. Since then, great advances have been made in gene discovery, revealing a genetic heterogeneity that extended pathophysiological mechanisms to non-ion channel biological pathways in focal epilepsies. The first mutations in a non-ion channel gene, leucine-rich glioma inactivated 1 (LGI1), were identified in families with autosomal dominant epilepsy with auditory features (ADEAF) (Kalachikov et al., 2002; Morante-Redolat et al., 2002). More recently, wholeexome sequencing identified mutations in the potassium channel KCNT1 gene in families with severe forms of ADNFLE with intellectual disability and psychiatric features (Heron et al., 2012). Lately, mutations in the DEPDC5 (dishevelled, Egl-10 and pleckstrin domain-containing protein 5) gene have been linked to diverse focal epileptic phenotypes, ranging from apparently nonlesional focal epilepsies to malformation-associated focal epileptic syndromes (for review (Baulac, 2014)). DEPDC5 is the major cause for familial focal epilepsy with variable foci (FFEVF), an autosomal dominant syndrome characterized by focal epileptic seizures arising from different cortical regions in different family members (Dibbens et al., 2013; Ishida et al., 2013). DEPDC5 mutations were also reported in 13 \% of a cohort of ADNFLE families (Picard et al., 2014) as well as families with focal epilepsies and focal cortical dysplasia (Baulac et al., 2015). Finally, a causative role for the corticotrophin-releasing hormone (CRH) gene has also been suggested in ADNFLE (Sansoni et al., 2013).

We will review the respective contribution of in vitro and in vivo models to the understanding of the pathogenic mechanisms of genetic focal epilepsies. Due to the current lack of functional studies concerning mutations in DEPDC5, we will focus on CHRNA4, CHRNB2, CHRNA2, KCNT1 and LGI1. This choice will allow us to exemplify both gain- and loss-of-function pathogenic mechanisms in focal epilepsies caused by mutations in ion channel and non-ion channel genes.

\section{INVESTIGATION METHODS AND M ODELS OF GENETIC FOCAL EPILEPSIES}

There is an abundant literature concerning the experimental procedures to induce seizures either chemically or by electroshocks. These models of acquired epilepsy will not be covered in this review. Instead, we will focus on investigation methods of genetic focal epilepsies, which follow a logical progression from cellular to animal models, offering specific and complementary advantages. 
Basically, in vitro models are needed to assess if a given genetic variant is responsible for the phenotype, while intact living organisms allow us to integrate pathomechanisms in neuronal networks and to recapitulate the clinical features observed in the patients. In addition, ex vivo techniques, including acute brain slices and organotypic cultures, are particularly used in epilepsy research paired with electrophysiology, but these will not be covered in this review. We provide a brief overview of the methods and models that are used step-by-step to link a mutation to its pathological consequences, together with their advantages and limitations.

\subsection{Types of disease-causing mutations}

Mutations are typically classified in different types, including most commonly missense, nonsense, splice-site and frameshift mutations. Missense mutations (a non-synonymous substitution) lead to an amino acid exchange in the protein sequence, which may modify the functional properties of the protein. Mutations found in ion channel genes are typically missense. In this case, the pathomechanism is defined as a gain-of-function. Additional dominant-positive or dominant-negative effects can act on associated proteins. The positional clustering of mutations along the gene can also provide useful clues regarding functional domains of the protein playing a key role in the pathology. In contrast, nonsense, splice-site and frameshift mutations lead to the introduction of a premature stop codon that may result in the truncation of the protein or its absence due to nonsense-mediated decay (NMD) degradation, the pathogenic mechanism being most likely a complete loss-of-function. Thus, the type of mutations constitutes a first piece of information to select the appropriate model and assess their functional consequences on the function of the protein of interest.

\subsection{Input of cellular models}

\subsubsection{Heterologous expression systems}

Once a genetic variant has been identified, the initial step is to determine if and how this variant affects protein function. This stage typically implies the generation of cellular models, in which rapid results may be obtained. When studying ion channels, heterologous expression systems are frequently used, in particular Xenopus oocytes and non-neuronal mammalian cell lines (for instance, human embryonic kidney [HEK-293T] cells). Expression of cDNA encoding wild-type (WT) or mutant proteins precedes in vitro analysis of their functional properties, to be explored with electrophysiological techniques. The advantage of using heterologous cells is the absence of the endogenous protein of interest, which facilitates the interpretation of the functional consequences of mutations. In vitro expression systems usually allow the distinguishing of neutral variants (with no effects on the trafficking/expression or on the intrinsic properties of the channel) and diseasecausing variants. However, species cDNA (human or rodent), type of expression vectors, transfection rates and cell types may influence the results and thus differ between studies. One major 
disadvantage of these heterologous systems resides in their differences from the physiological (i.e. neuronal) environment, which strongly influences the functions of proteins.

\subsubsection{Neuronal expression systems}

When studying epilepsy, neuronal cells are often indispensable to study the expression, intracellular trafficking and binding characteristics of a protein of interest, either in its endogenous form or overexpressed as a mutant or WT form. Neuronal systems mainly include a restricted number of neuronal cell lines (for instance PC12, N2a and SH-SY5Y cells) and primary neuronal cultures from rodents. Although conceptually interesting, the use of the latter is limited since their viability is restricted in time and transfection is inefficient. Besides these technical issues, this approach also presents scientific drawbacks. First, expression of endogenous proteins complicates the study of overexpressed mutated proteins: for example, other ion channels with closely related functions can mask the detection of subtle defects in the one studied. Second, maturation stages of primary cultured neurons, mostly embryonic, may differ from pathogenic mature neurons in patients. Finally, though closer to neural physiology than heterologous systems, an essential component for epileptogenesis, seizure generation and propagation is missing in cultured neurons: the architectural organization of neural networks and cerebral structures. Taken together, heterologous and neuronal expression systems are precious basic tools to assess the effect of a given mutation at singlemolecule/cell levels. Yet, more complex models, namely intact living organisms, are required to explore pathophysiological mechanisms underlying genetic focal epilepsies at fully integrated levels.

\subsection{Animal models}

Genetically engineered animal models are particularly suitable to understand the neurobiology of a specific inherited epilepsy syndrome. Mouse models have become standard in vivo models but, zebrafish and rat models have also more sporadically emerged. A diversification of available genetic animal models will certainly occur in the coming years with the advancement in gene-editing technologies, such as TALENs (transcription activator-like effector nucleases) and CRISPRs (clustered regularly interspaced short palindromic repeats) which can add, disrupt or change targeted sequences of DNA. Animal models are required to fulfill a number of validity criteria, including construct validity, face validity and predictive validity criteria (Grone and Baraban, 2015). Animals should recapitulate the causal mechanisms underlying the epilepsy syndrome (i.e. the genetic defect), and with an appropriate design mimic the human mutation (construct validity). Knockout (KO) models, in which the target gene is disrupted by homologous recombination or by newer geneediting techniques such as CRISPRs, are suitable to mimic a complete loss-of-function mechanism (when modeling nonsense and frameshift mutations). Constitutive (or global) KO delete permanently the gene of interest in all cells of a given organism. Conditional knockouts inactivate gene expression 
in a specific target tissue and/or in a time-controlled manner using a Cre/loxP strategy. Knock-in (KI) models, defined by the replacement of endogenous alleles by mutated alleles, are used to reproduce missense mutations, and are therefore particularly useful in the case of gain-of-function pathomechanisms and to link a given mutation to a specific phenotype. Heterozygous KI models are also relevant models to replicate dominant-positive or -negative effects. Overexpressing (OE) transgenic models, consisting of random insertion of several copies of the gene of interest (mutated or WT), have been widely used in the past because of the short development time to produce them, but tend to be replaced by knock-in models that are more physiological. Face validity is the ability to reproduce the phenotypic features of the human disorder. Animal models of epilepsy should ideally display spontaneous and recurrent seizures that reflect their human equivalents in terms of age at onset and semiology (both behavioral manifestations and electroencephalogram (EEG) patterns). Lastly, predictive validity refers to the ability of an animal model to correctly identify the efficacy of novel antiepileptic drugs. To date, none of the existing animal models of monogenic focal epilepsies fully meet all validity criteria and replicate the human disorder. However, despite this and technical difficulties, including time constraints and costs, animal models continue to play an essential part in elucidating molecular, functional and anatomical aspects of genetic focal epilepsies. Numerous genetically engineered animal models already exist, among which scn1a-/- mice (Yu et al., 2006), scn1b-/- mice (Chen et al., 2004) and gabrg2-KI (Tan et al., 2007), which mutations in Human lead to generalized seizures and occasionally focal seizures. In this review, we will only focus on models reported to reproduce autosomal dominant focal epilepsies.

\section{ADNFLE MUTATIONS IN NICOTINIC ACETYLCHOLINE RECEPTOR GENES}

\subsection{Genetic basis of autosomal dominant frontal lobe epilepsy (ADNFLE)}

Autosomal dominant nocturnal frontal lobe epilepsy (ADNFLE) has been reported in hundreds of families. ADNFLE is a syndrome characterized by clusters of sleep-related motor seizures and an average age at onset between 8 and 12 years. Ictal semiology includes a wide spectrum of motor manifestations, ranging from brief tonic events to major hyperkinetic episodes (Marini and Guerrini, 2007; Picard and Scheffer, 2012). Although ADNFLE was initially described as a rather benign and clinically homogeneous epilepsy, psychiatric symptoms and cognitive impairment appear to also take part in the broad ADNFLE phenotype, with intra- and inter-familial variability. Carbamazepine is the first choice drug for controlling seizures in ADNFLE patients, but drug resistance is reported in about $30 \%$ of patients (Picard et al., 2000; Picard et al., 2009). Cases of sporadic nocturnal frontal lobe epilepsy (NFLE) also exist, with clinical manifestations indistinguishable from familial forms (Combi et al., 2004). 
A limited number of disease-causing mutations in three genes (CHRNA2, CHRNA4 and CHRNB2) encoding the respective $\alpha 2, \alpha 4$ and $\beta 2$ subunits of the $n A C h R$ have been associated with ADNFLE families and sporadic NFLE patients. To date, a total of six distinct mutations in CHRNA4, six in CHRNB2 and two in CHRNA2 have been reported (Table 1). To note, S280F and S284L mutations in CHRNA4 appear to be mutational hot spots since several families and sporadic cases carry these specific mutations. The second mutation in CHRNA2 (I297F) was recently identified in a large family, confirming the involvement of this gene in ADNFLE (Conti et al., 2015). Five CHRNA4 mutations cluster in the second transmembrane (TM2) domain and five CHRNB2 mutations are located either at the TM2-TM3 loop or within TM3; the two CHRNA2 mutations are located in TM1 and TM2. The TM2-TM3 region plays an essential part in controlling the opening and closing kinetics of nAChRs. Mutations in CHRNA4, CHRNB2 and CHRNA2 collectively account for only a minority of ADNFLE families, indicating that ADNFLE is genetically heterogeneous (Steinlein, 2014). All ADNFLE mutations in CHRNA2, CHRNA4 and CHRNB2 are missense to the exception of a three base pair insertion in CHRNA4 leading to an additional leucine residue in the protein sequence (L291dup). There are no loss-of-function mutation reported so far.

\subsection{In vitro models: towards a gain-of-function effect}

Neuronal nAChRs are pentameric ligand-gated ion channels that response to endogenous neuromodulator acetylcholine (ACh) and exogenous nicotine. These receptors are encoded by nine $\alpha$ and three $\beta$ subunit genes and are widely distributed throughout the mammalian brain with various combinations of five subunits, $\alpha 4_{2} / \beta 2_{3}$ heteromers being one of the most frequent combinations in the brain. Neuronal nAChRs are preferentially expressed in presynaptic and preterminal localizations, modulating excitatory and inhibitory neurotransmitter release. Postsynaptic and nonsynaptic nAChRs also play important roles and may influence neuronal excitability. The broad action of nAChRs may explain their involvement in a variety of physiological processes (including learning and memory and regulation of mood) or in drug dependence, Alzheimer's or Parkinson's diseases, and may also explain cognitive and psychiatric symptoms associated with ADNFLE (Dani and Bertrand, 2007). Numerous electrophysiological studies in heterologous expression systems including Xenopus oocytes and mammalian cells, have attempted to elucidate how disease-causing mutations may alter the properties of nAChRs. Due to the heterogeneity of expression systems, cDNA species and homozygous or heterozygous simulated situation, comparisons between studies are difficult. Nevertheless, most studies agreed that mutations in CHRNA4, CHRNB2 or CHRNA2 have no or little effect on the assembly and membrane expression of nAChRs in heterologous cells (Figl et al., 1998; Kuryatov et al., 1997; Phillips et al., 2001). In contrast, mutations cause alterations of nAChR functional properties, although divergent conclusions have been reported. Several studies have 
investigated the consequences of the recurrent S280F- $\alpha 4$ mutation in heterologous systems, when expressed at the homozygous state. Different observations have been made, ranging from S280F- $\alpha 4$ inducing a faster desensitization (Bertrand et al., 1998; Figl et al., 1998; Kuryatov et al., 1997; Weiland et al., 1996), a decreased ACh sensitivity (Bertrand et al., 1998) or a use-dependent potentiation of nAChRs (Figl et al., 1998; Kuryatov et al., 1997), suggesting both gain- or loss-offunction mechanisms. Similarly, L291dup- $\alpha 4$, when expressed at the homozygous state, resulted both in negative effect by lowering $\mathrm{Ca}^{2+}$ permeability (Figl et al., 1998; Steinlein et al., 1997), and positive effects by increasing ACh sensitivity (Bertrand et al., 1998; Steinlein et al., 1997) and inducing a use-dependent potentiation of the ACh response (Figl et al., 1998). When expressed at the heterozygous state, to mimic the situation in humans, a convergent gain-of-function effect emerged for CHRNA4 and CHRNB2 mutations (Table 1). S284L- $\alpha 4$ and V287M- $\beta 2$ variants caused a reduced dependence of the ACh response to $\mathrm{Ca}^{2+}$ and an increased sensitivity to ACh (Bertrand et al., 2002; Phillips et al., 2001; Rodrigues-Pinguet et al., 2003). Increased sensitivity to ACh was also caused by S280F- $\alpha 4$, L291dup- $\alpha 4$ and T293I- $\alpha 4$ mutations, and M301V- $\beta 2$, V308A- $\beta 2$ and I312M- $\beta 2$ mutations (Bertrand et al., 2005; Bertrand et al., 2002; Hoda et al., 2008; Leniger et al., 2003), leading to activation of nAChRs at low concentrations of $\mathrm{ACh}$, thus increasing their probability of opening (Bertrand et al., 2002; Hoda et al., 2008; Leniger et al., 2003; Phillips et al., 2001; Teper et al., 2007). In contrast, the effects of $\alpha 2$-mutations on nAChR properties are still uncertain since $1279 \mathrm{~N}-\alpha 2$ resulted in a gain-of-function consisting of an increased sensitivity to the exogenous agonist nicotine (Aridon et al., 2006), whereas the 1297F- $\alpha 2$ mutation caused a decreased nicotine-induced current (Conti et al., 2015), when expressed heterozygously in HEK-293T cells.

In summary, in vitro studies confirmed the pathogenicity of ADNFLE mutations and revealed a gainof-function of mutated nAChRs. Although diverse effects have been reported, they all tended towards an overall increase in nAChR function. The prolonged activation of presynaptic nAChRs may lead to an increased neurotransmitter release. The link between this putative enhanced synaptic transmission and hyperexcitability still needs to be further characterized, and would probably benefit from investigations in neuronal expression systems. Due to the diversity of receptor location in neurons and subunit composition in the brain, in vivo studies are essential to explore mutational effects at synaptic and network levels.

\subsection{M urine models of ADNFLE}

\subsection{1 nAChR mutations induce seizures and sleep-related phenotypes}

Numerous murine models of ADNFLE including knock-in (KI) and overexpressing (OE) transgenic mouse and rat models of CHRNA4 and CHRNB2 have been generated (Table 2) (also reviewed in (Steinlein, 2010)). Most murine models of ADNFLE presented an epileptic phenotype, either 
spontaneously or induced by nicotine. None of them entirely recapitulated the ADNFLE phenotype but they mimicked some of the clinical features of patients. In contrast, homozygous knockout mice of Chrna4 (Ross et al., 2000), Chrnb2 (Picciotto et al., 1995) or Chrna2 (Lotfipour et al., 2013) gene did not display spontaneous or nicotine-induced epileptic phenotype supporting the hypothesis that complete loss-of-function of $n A C h R$ subunits did not underlie ADNFLE.

\subsubsection{Nicotine-induced seizures}

The first genetically-engineered animal model was a $\mathrm{KI}$ mouse named L9'A- $\alpha 4$ corresponding to L287A- $\alpha 4$ (Fonck et al., 2005). Although no disease-causing mutations have been reported in the corresponding human amino acid L283, its proximity to reported mutations in TM2 made this model relevant to ADNFLE. Despite the absence of a spontaneous epileptic phenotype, heterozygous L9'Aa4 KI mice exhibited a hypersensitivity to nicotine-induced seizures (Fonck et al., 2005). Subsequently, two KI mouse models of ADNFLE mutations were generated: both heterozygous L291dup- $\alpha 4$ and S280F- $\alpha 4$ KI mice also exhibited increased sensitivity to nicotine (Klaassen et al., 2006). Homozygous V287L- $\beta 2$ KI mice (O'Neill et al., 2013) and heterozygous S280F- $\alpha 4$ KI mice (Teper et al., 2007) displayed dystonic arousal complexes (DAC), characterized by stereotypical head movements, body jerking and forelimb dystonia and resembled dystonic head and limb elements of ADNFLE patients. Heterozygous L9'A- $\alpha 4$ KI mice (Fonck et al., 2005) and S284L- $\alpha 4$ OE rats (Zhu et al., 2008) exhibited focal seizures in response to high-dose injections of nicotine whereas control animals displayed generalized seizures. Overall, quantitative and qualitative differences of response to nicotine-induced seizures are common features of rodent models engineered with nAChR mutations.

\subsubsection{Spontaneous epileptic seizures}

Spontaneous seizures with a typical EEG activity pattern were reported in two distinct $\alpha 4$ murine models: L291dup- $\alpha 4 \mathrm{KI}$ mice and S280F- $\alpha 4 \mathrm{KI}$ mice (Klaassen et al., 2006), and in one $\beta 2$ mouse model (V287L- $\beta 2$ OE mice) (Manfredi et al., 2009). Heterozygous L291dup- $\alpha 4 \mathrm{KI}$ and S280F- $\alpha 4 \mathrm{KI}$ mice showed frequent spontaneous seizures (several/hour), ranging from brief periods of behavioral arrest to long periods of rhythmic, jerking motion of all limbs and loss of equilibrium with falls (Klaassen et al., 2006). Interestingly, another strain of S280F- $\alpha 4$ KI mice did not present spontaneous seizures (Teper et al., 2007), reflecting the importance of the genetic background on top of engineered mutations in seizure susceptibility. The spontaneous epileptic phenotype observed in V287L- $\beta 2$ OE mice consisted of very frequent interictal spikes of high amplitude and seizures. The severity depended on the transgene expression level since a mouse strain with low expression only displayed rare and brief spontaneous seizures while another strain with higher expression had more frequent and longer episodes (Manfredi et al., 2009).

Additionally, a rat model, S284L- $\alpha 4$ OE, was produced. S284L- $\alpha 4$ OE rats exhibited a spontaneous epileptic phenotype consisting of frequent interictal discharges and seizures occurring 
on average once a week (Zhu et al., 2008). Interictal discharges, integrated in the thalamocortical loop, originated from the sensorimotor cortex and propagated to the ventrolateral nucleus of the thalamus and basolateral amygdala. Seizures were described as paroxysmal arousals (brief episodes with frightened expression), paroxysmal dystonia (brief episodes of dystonic posturing), and epileptic wandering (ambulation with head shaking and bizarre movements). In contrast to most ADNFLE cases, patients carrying the S284L- $\alpha 4$ mutation are not good responders to carbamazepine (Combi et al., 2004). Interestingly, the pharmacological response of S284L- $\alpha 4$ OE rats was similar to that of patients since carbamazepine was ineffective, while diazepam and zonisamide reduced interictal discharge frequency (Zhu et al., 2008). Altogether, seizure phenotype and antiepileptic drug response indicated that S284L- $\alpha 4$ OE rats are a pertinent model for ADNFLE (Steinlein, 2010).

\subsubsection{Sleep-related phenotype}

Circadian rhythm was explored in L9'A- $\alpha 4 \mathrm{KI}$ and V287L- $\beta 2 \mathrm{KI}$ mice. In both models, the activity-rest cycle was found to be altered. Sleep-wake transitions were more frequent in homozygous L9'A- $\alpha 4$ KI mice whereas brief awakenings, lasting a few seconds, were more frequent in both heterozygous and homozygous animals compared to WT mice (Fonck et al., 2005). Homozygous V287L-B2 KI mice displayed an increased activity during the light cycle that suggested disturbances in sleep patterns (Xu et al., 2011). Interestingly, the frequent interictal discharges and the seizures exhibited by S284La4 OE rats occurred exclusively during slow-wave sleep, as in patients with NFLE (Zhu et al., 2008).

\subsubsection{Dysfunction of GABAergic transmission}

Heterozygous L291dup- $\alpha 4$ and S280F- $\alpha 4$ knock-in mice showed a robust increase in nicotinic-evoked GABAergic cortical inhibition by increasing synaptic release of GABA in layer II/III pyramidal cells from frontal cortex slices. In contrast, nicotine had no effect on excitatory transmission. The authors hypothesized that seizure generation resulted from a hypersynchronization of cortical pyramidal cells that follows recovery from the massive inhibition (Klaassen et al., 2006). Conversely, in S284L- $\alpha 4$ OE rats, an attenuation of GABAergic transmission was demonstrated before seizure onset (Zhu et al., 2008). Recordings from layer $V$ pyramidal cells of the sensorimotor cortex (the focus region) before seizure onset (4 weeks after birth) showed a lower frequency of spontaneous inhibitory postsynaptic currents in S284L-a4 OE rats compared to WT without changes in excitatory transmission. It was suggested that this initial reduction of GABAergic transmission could in turn explain the increased glutamate release showed by S284L-a4 OE rats at seizure onset ( 8 weeks of age), in particular during sleep (Yamada et al., 2013; Zhu et al., 2008). Taken together, animal models suggested that ADNFLE initial pathogenic mechanisms rely on dysfunctional GABAergic transmission.

\subsubsection{Epileptogenesis is restricted to a critical period}

V287L- $\beta 2$ OE mice overexpressed the CHRNB2 transgene under the drive of an inducible neuronalspecific tetracycline promoter, allowing the transgene to be reversibly silenced by doxycycline 
administration (Manfredi et al., 2009). While untreated mice showed interictal spikes and spontaneous seizures, silencing the transgene during the two first postnatal weeks prevented the emergence of seizures. However, administration of doxycycline to adult mice had no effect on seizures. Accordingly, diuretic furosemide administration to S284L- $\alpha 4$ OE rats before seizure onset reduced both the proportion of rats exhibiting seizures and the seizure frequency, while it had no significant effect when administered after seizure onset (Yamada et al., 2013). It thus seems that epileptogenesis in ADNFLE models occurs during a critical period in young animals and that early expression of mutated nAChRs causes long-lasting structural and/or functional alterations that lead to seizures. Interpretation of recent data obtained from neocortical cultures of V287L- $\beta 2$ OE mice suggested that CHRNB2 mutations affect the dynamics of synaptic transmission, especially during its maturation, thus agreeing with the hypothesis of functional defects (Gullo et al., 2014). In conclusion, all cellular and animal models of nAChR genes-related to ADNFLE excluded a complete loss-offunction of mutated alleles. Mutated nAChR subunit genes cause abnormal functional properties that may cause a dominant-negative effect on associated subunits in pentameric nAChRs. GABAergic transmission was found to be altered in several animal models exhibiting spontaneous seizures. However, numerous questions remain unresolved in order to understand seizure emergence in ADNFLE. Among them, the link between a given mutation and its phenotypic expression, including comorbidities, still needs to be addressed, as well as the focal nature of seizures considering the ubiquitous expression of $\mathrm{nAChRs}$ in the central nervous sytem.

\section{ADNFLE MUTATIONS IN POTASSIUM CHANNEL KCNT1 GENE}

The KCNT1 channel underlies a $\mathrm{Na}^{+}$-gated $\mathrm{K}^{+}$channel which is specifically blocked by quinidine (Kim et al., 2014). KCNT1 mutations were recently linked to severe ADNFLE presenting an earlier mean age of onset and association with intellectual disabilities and psychiatric features (Heron et al., 2012). So far, four missense mutations have been reported in KCNT1 in NFLE: 3 inherited and one de novo. Interestingly, mutations in KCNT1 also cause malignant migrating partial seizures of infancy (MMPSI) and Ohtahara syndrome, two severe forms of early-onset epilepsies (Barcia et al., 2012; Martin et al., 2014). The electrophysiological properties of ADNFLE-associated KCNT1 mutations (M896I, R398Q, Y796H and R928C) and of MMPSI mutations (R428Q, A934T and P924L) were examined in Xenopus oocytes. All disease-causing KCNT1 mutations produced higher currents than the WT, causing a marked increase in function (Milligan et al., 2014). The effect was even greater in MMPSI mutations than ADNFLE mutations, suggesting a correlation between the in vitro effects and the severity of the phenotype. However, the existence of an identical mutation identified in both a patient with MMPSI and a patient with ADNFLE, suggests that other factors influence the phenotype (Kim et al., 2014). To 
date, more than 30 cases of epilepsy patients have been reported with a KCNT1 mutation in a wide phenotypic spectrum indicating KCNT1 may not be a specific gene for ADNFLE. Preliminary clinical evidence shows that quinidine may be an effective medication for epilepsy syndromes due to gainof-function mutations in KCNT1 (Bearden et al., 2014)

\section{ADEAF MUTATIONS IN LGI1 GENE}

\subsection{Genetic basis of autosomal dominant epilepsy with auditory features (ADEAF)}

ADEAF refers to an inherited focal epilepsy with a relatively benign outcome and a good response to standard antiepileptic drugs (Michelucci et al., 2009; Winawer et al., 2000). ADEAF is a well-defined and homogenous condition consisting of adolescence / early adulthood-onset lateral temporal seizures. Seizures are predominantly characterized by auditory auras and by a high propensity to secondary generalized tonic-clonic seizures. Aphasic seizures, alone or in association with auditory symptoms, and visual hallucinations are also frequently reported in ADEAF patients. Conventional magnetic resonance imaging (MRI) is normal.

Leucine-rich, glioma inactivated 1 (LGI1) gene was first shown to be interrupted by a chromosome 10 translocation in a glioblastoma cell line (Chernova et al., 1998). A few years later, two groups discovered LGI1 disease-causing mutations in families with ADEAF presenting linkage to chromosome 10q (Kalachikov et al., 2002; Morante-Redolat et al., 2002). Currently, 45 ADEAF families and 3 sporadic cases have been reported listing 42 distinct LGI1 mutations (Table 3). These 42 mutations, including 27 missense (64\%), 7 frameshift (17\%), 4 splice-site (10\%), 2 nonsense mutations (4.5\%) and 2 deletions (4.5\%), are evenly distributed along the gene. A loss-of-function is the most likely general pathogenic mechanism underlying LGI1-related epilepsy given that more than a third of mutations lead to the introduction of a premature termination codon. The rather homogeneous phenotype displayed by patients is in accordance with this common mechanism. No correlation has been found between the mutation type or its position within the gene and particular clinical features (Nobile et al., 2009; Rosanoff and Ottman, 2008). LGI1 mutations account for 30 to $50 \%$ of ADEAF families, suggesting a still unresolved genetic heterogeneity. In addition to its role in inherited epilepsies, LGI1 is involved in a subset of patients with acquired autoimmune limbic encephalitis (Irani et al., 2010; Lai et al., 2010). Autoimmune encephalitis refers to an adult-onset neurological disorder associated with antibodies against variable extracellular epitopes, including LGI1, previously attributed to voltage-gated potassium channels (VGKC). Limbic encephalitis is characterized by neurologic and psychiatric symptoms: memory loss and confusion, seizures and hippocampal abnormalities. 
LGI1 was the first non-ion channel gene to be directly linked to epilepsy in humans. The protein is composed of a signal peptide at the $\mathrm{N}$-terminus, followed by four leucine-rich repeat (LRR) domains flanked by two cysteine clusters and seven copies of a repeat of about 45 residues named EAR (epilepsy-associated repeat) or EPTP (epitempin). LGI1 belongs to a family of genes including three other paralogs: LGI2, LGI3 and LGI4 (Scheel et al., 2002; Staub et al., 2002). Although these paralogs are pertinent candidates for epilepsies, no disease-causing mutations have been reported so far (Kegel et al., 2013).

\subsection{Exploring LGI1 function using cellular models}

\subsubsection{ADEAF mutations impair secretion in vitro}

A secretion-competent heterologous expression system, LGI1 transfected HEK-293T cells, provided the first experimental evidence that LGI1 was secreted (Senechal et al., 2005). Subsequently, secretion was confirmed to be a distinctive feature of LGI1 in different mammalian cell types such as COS7 (Sirerol-Piquer et al., 2006), CHO and PC12 cells (Chabrol et al., 2007; de Bellescize et al., 2009) and cultured hippocampal neurons (Fukata et al., 2006). LGI1 protein is $\mathrm{N}$-glycosylated in the endoplasmic reticulum (ER) and matured through the secretory pathway. Interestingly, all ADEAFcausing mutations tested, with the exception of three missense mutations (R407C, S473L, R474Q) (Striano et al., 2011; Yokoi et al., 2015), impaired the secretion of the protein in transfected mammalian cells (Table 3). Secretion-defective mutant proteins were unstable and accumulated in the ER and Golgi complex before premature degradation (Sirerol-Piquer et al., 2006). In a recent study of 19 secretion-defective LGI1 missense mutations, variability in the strength of the secretion was reported (Yokoi et al., 2015). As an alternative mechanism, LGI1 secretion-competent mutation (S473L) showed a much weaker binding to one of its protein partners, ADAM22, compared to wildtype LGI1 (Yokoi et al., 2015). These studies confirmed that LGI1-related epilepsy resulted from a loss-of-function mechanism and demonstrated the decisive role played by extracellular LGI1 in the pathogenesis.

\subsubsection{Identification of LGI1 binding partners}

LGI1 protein was copurified with the voltage-gated potassium channel subunit Kv1.1 from rat brain lysate (Schulte et al., 2006). Presynaptic A-type channels, of which Kv1.1 is a major constituent, are responsible for adjusting synaptic transmission in the central nervous system by regulating neurotransmitter release. The functional relevance of LGI1-Kv1.1 interaction was investigated in Xenopus oocytes: LGI1 slowed the inactivation of Kv1.1-Kv $\beta 1$ channels by interacting with the cytosolic Kv $\beta 1$ subunit. Conversely, truncated LGI1 failed to prevent Kv $\beta 1$-mediated inactivation (Schulte et al., 2006). In the mean time, in the search for PSD-95 binding partners, LGI1 was copurified from rat brain lysate with ADAM22 (A Disintegrin And Metalloprotease domain) 
transmembrane protein (Fukata et al., 2006). Colocalization of LGI1 and ADAM22 at the cell surface of transfected mammalian cells and hippocampal neurons was further confirmed (Fukata et al., 2006; Fukata et al., 2010). ADAM22 is a brain specific metalloproteinase lacking catalytic activity (Sagane et al., 2008) and is currently considered as the main receptor of LGI1. The direct interaction is mediated by EPTP domains of LGI1 and the extracellular domain of ADAM22. Two additional LGI1 ligands were identified from transfected mammalian cells and mouse brain purification: ADAM23 and ADAM11, two other neuronal catalytically-deficient ADAM family members (Fukata et al., 2010; Owuor et al., 2009; Sagane et al., 2008). A hypothesis that still needs to be proven postulates that LGI1 forms a transsynaptic bridge between presynaptic ADAM23 and postsynaptic ADAM22 proteins (Fukata et al., 2010). It was recently reported that auto-antibodies against LGI1 from patients with limbic encephalitis inhibited the binding of LGI 1 to ADAM22 and ADAM23 in transfected mammalian cells (Ohkawa et al., 2013). Therefore, the pathophysiology of LGI1-related limbic encephalitis, also probably relies on a loss-of-function mechanism. Interestingly, membrane-surface clustering of Kv1 channels, including Kv1.1, is mediated by PSD-95 and ADAM22 (Kim et al., 1995; Ogawa et al., 2010). It is likely that Kv1 channels, ADAM22, PSD-95 and LGI1 form part of a multi-protein complex.

\subsubsection{Role of LGI1 in the regulation of neurite growth}

The LRR domains of LGI1 are close homologues of the secreted SLIT proteins involved in axonal growth and guidance in the nervous system (Blockus and Chedotal, 2014; Krex et al., 2002). Based on the assumption that structural similarities shared by LGI1 and SLIT might underlie functional similarities, a study showed that LGI1 antagonized myelin-induced inhibition of neurite outgrowth and growth cone collapse in both cultures from rat cerebellar granule neurons and chick dorsal root ganglion (DRG) sensory neurons. LGI1 mediated this action by binding in vitro to Nogo receptor 1 (NgR1), a transmembrane protein, in association with ADAM22 (Thomas et al., 2010). Another study has shown that LGI1 stimulated neurite outgrowth of DRG and hippocampal neurons through its interaction with ADAM23, even in the absence of myelin substrate (Owuor et al., 2009). Taken together, these data suggest that LGI1 contributes in vitro to shape neurite morphology.

In summary, in vitro models have confirmed that LGI1 is a secreted protein, and demonstrated that the vast majority of ADEAF-mutations prevent its secretion. In addition, the identification of its binding partners, including ADAM22, ADAM23, ADAM11, Kv1.1 and NgR1, provided the first elements to understand LGI1 function(s).

\subsection{Animal models of ADEAF}

\subsubsection{Animal models of LGI1-deficiency are epileptic}

5.3.1.1 Lgi1 knockdown in zebrafish 
Morpholinos (MO) were used to reduce the expression of Igila, one of the two LGI1 homologues in zebrafish. High-dose MO targeting Igila triggered seizure-like behaviors consisting of hyperactivity and erratic swimming, reduced brain and eye size, and high mortality rates (Teng et al., 2010). Lack of electrophysiological recordings precluded to firmly conclude that morphant Igila fishes exhibited epileptic seizures. With low-dose MO, morphant fishes were morphologically normal, and were more vulnerable to convulsant pentylenetetrazole (PTZ)-induced seizures than control animals (Teng et al., 2010). The correlation between the severity of the phenotype and the reduction of Igila expression was consistent with the loss-of-function hypothesis. Additionally, the structural neural abnormalities induced by an embryonic lack of Igi1a in zebrafish suggested that these abnormalities may contribute to the pathomechanisms of seizures. Knockdown of the Igilb gene produced developmental abnormalities but no spontaneous seizure-like behavior. However, Igilb morphants were more susceptible to PTZ-induced hyperactivity (Teng et al., 2011).

\subsubsection{Lgi1 mouse models (Table 4)}

Three independent strains of knockout (KO) mice that completely lack Lgi1 were generated, on two genetic backgrounds (C57BI/6 and albino C57BI/6). All strains of homozygous KO (Lgi1-/-) mice presented early-onset frequent spontaneous seizures (Chabrol et al., 2010; Fukata et al., 2006; Yu et al., 2010). Lgi1-/- had normal behavior and appearance at birth. During the second postnatal week, spontaneous epileptic seizures emerged, accompanied by EEG abnormalities with a generalized pattern (Yu et al., 2010) or that may originated in the hippocampus (Chabrol et al., 2010). A strong reduction of body weight was observed in Lgi1-/- mice that died at 2-3 weeks of age (Chabrol et al., 2010; Fukata et al., 2006; Yu et al., 2010). No major neuroanatomical abnormalities were detected before seizure onset (P10). However, after recurrent seizures, Lgi1-/- mice displayed neuronal loss, mossy fiber sprouting, astrocyte reactivity and granule cell dispersion in the hippocampus (Chabrol et al., 2010). Heterozygous KO mice (Lgi1+/-) were fertile, had no spontaneous seizure and survived normally. However, they were more susceptible to sound-induced (Chabrol et al., 2010) or PTZinduced seizures (Fukata et al., 2006). In summary, Lgi1+/- mice recapitulate the genetic cause and mimic the human condition with an auditory epileptogenic trigger, while Lgi1-/- mice present early onset spontaneous seizures with a probable origin in the temporal lobe structures. It is interesting to note that homozygous KO mouse models of several LGI1 binding partners, namely ADAM22, ADAM23 and Kv1.1, exhibited a phenotype with epilepsy and premature death similar to that of Lgi1/- mice (Mitchell et al., 2001; Owuor et al., 2009; Smart et al., 1998). Transgenic mice overexpressing either WT (Lgi1-OE-WT) or a truncated form of Lgi1 protein (Lgi1-OE-835delC) were engineered. No spontaneous seizures were detected in either of the lines but Lgi1-OE-835delC mice were more susceptible to PTZ-induced seizures than WT littermates and Lgi1-OE-WT mice (Zhou et al., 2009). Recently, mice overexpressing a mutant Lgi1 transgene with an ADEAF missense mutation (either the 


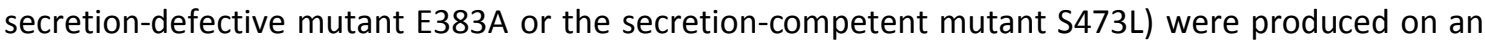
Lgi1-/- background (Yokoi et al., 2015). Similarly to Lgi1-/- mice, both Lgi1-/-;Li1-OE-E383A and Lgi1/-;Lgi1-OE-S473L mice presented frequent spontaneous seizures and premature death, confirming that the secretion-competent S473L mutation is deleterious. In contrast, Lgi1+/-;Lgi1-OE-E383A and Lgi1+/-;Lgi1-OE-S473L mice had no spontaneous seizures, but increased susceptibility to PTZ-induced seizures, a similar phenotype to that of Lgi1+/- mice, suggesting that ADEAF-causing mutations do not act as dominant-negative (Yokoi et al., 2015).

\subsubsection{Lgi1 knock-in rats (Table 4)}

Rats carrying the missense mutation L385R at a highly conserved residue in the fourth EPTP domain close to the ADEAF E383A mutation were generated by ENU ( $\mathrm{N}$-ethyl-N-nitrosourea) mutagenesis (Baulac et al., 2012). Spontaneous and frequent epileptic seizures, typically consisting of hypertonic trunk, limb and tail postures and clonies of all limbs or jerking, were observed from postnatal day P10

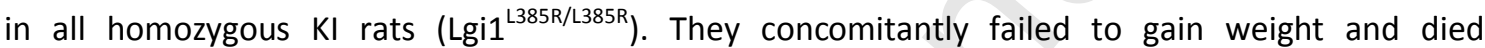
prematurely before P17. Reminiscent of the Lgi1+/- mouse phenotype, Lgi1 ${ }^{+/ L 385 R}$ rats were fertile and survived normally. No spontaneous epileptic seizure was ever observed, but they presented high vulnerability to audiogenic seizures, like ADEAF patients. Mutant protein L385R-Lgi1 was not detectable in rat brain lysates from Lgi1 ${ }^{\mathrm{L} 385 R / L 385 R}$ rats and was reduced by half in $\mathrm{Lgi1}^{+/ L 385 R}$ compared to control littermates, suggesting instability and premature degradation of the mutant protein (Baulac et al., 2012). A similar observation was done in Lgi1-OE-E383A mice indicating that Lgi1E383A mutant protein may be misfolded (Yokoi et al., 2015).

\subsubsection{LGI1-deficiency induces glutamatergic transmission defects}

Murine models have also allowed great advances in the understanding of pathogenic mechanisms underlying LGI1-related epilepsy, pointing toward a defect of glutamatergic transmission. The first study, in transgenic Lgi1-OE mice, revealed a role in the postnatal maturation of glutamatergic synapses both pre- and postsynaptically as well as in the structural pruning of glutamatergic neurons (Zhou et al., 2009). Moreover, in Lgi1-OE-WT mice, retinogeniculate axon pruning was accelerated in the developing visual system (Zhou et al., 2012). The role of LGI1 in glutamatergic transmission was further confirmed by studies in KO mice. Fukata and colleagues reported that the binding of LGI1 to ADAM22 enhances the number of AMPA receptors at the synapse, therefore increasing the glutamatergic transmission (Fukata et al., 2006). Electrophysiological recordings of CA1 hippocampal pyramidal neurons on brain slices revealed that the amplitude of miniature excitatory postsynaptic currents (mEPSCs) and the AMPA/NMDA ratio were decreased in Lgi1-/- mice, whereas mEPSCs frequency was unaltered (Fukata et al., 2010). In contrast, Yu and colleagues reported opposite results, with increased frequency of mEPSCs but no change in amplitude, and increased amplitude of both evoked AMPA and NMDA currents, suggesting a presynaptic defect due to increased release of 
glutamate (Yu et al., 2010). One reason for these contradicting conclusions may result from different seizure histories and seizure-induced brain damages present in Lgi1-/- mice (Anderson, 2010). In summary, acute brain slices of Lgi1 mouse models all agreed that LGI1 plays a role in the glutamatergic transmission. Recent work from our laboratory confirmed the link between LGI1 and excitatory transmission with in vivo studies in Lgi1 conditional KO mice models. Lgi1 deletion, restricted to cortical glutamatergic neurons from embryogenesis (Emx1-cKO mice), was sufficient to induce a spontaneous severe epileptic phenotype and premature death within the first month after birth, close to that of Lgi1-/- mice (Boillot et al., 2014). In contrast, neither spontaneous seizures nor increased seizure susceptibility to PTZ were observed when Lgil was specifically deleted in GABAergic parvalbumin interneurons (PV-cKO mice) (Boillot et al., 2014). This study demonstrated in vivo that glutamatergic neurons are the main contributors to the pathogenesis of LGI1-related epilepsy.

\subsubsection{LGI1 is essential during the whole life}

Another fundamental question is whether the role of LGI1 in epileptogenesis is purely neurodevelopmental or whether depletion of the protein in adult can also trigger seizures. Another strain of conditional deletion of Lgi1 restricted to adult forebrain glutamatergic neurons was produced (CaMKII-cKO mice) (Boillot et al., 2014). Occasional spontaneous seizures with EEG abnormalities were recorded in CaMKII-cKO mice showing that loss of Lgi1 beyond the early postnatal developmental period can also trigger seizures later in life. This study demonstrated that LGI1 is critical during the whole life, as it was suggested by the adult-onset of limbic encephalitis with LGI1 autoantibodies.

In summary, both in vitro functional evidence and the spontaneous epileptic phenotype consistently presented by all Lgi1-deficient animal models supported that complete loss-of-function is the most convincing mechanism for LGI1 mutations. Multiple functions of LGI1 have been proposed thanks to cellular and animal models, although the direct link with epilepsy still remains to be specified. Currently, the process of confirming in vivo the interesting avenues provided by in vitro data is the key step to fully resolve LGI1 function. Among them, it seems essential to establish whether LGI1 has distinct roles throughout life and how the disruption of LGI1 molecular complex integrity leads to a dysfunction of glutamatergic transmission.

\section{CONCLUSIONS}

Seizures are the visible end point of a long chain of deficient mechanisms going from molecular to network levels. Epilepsy genes constitute an entry point into the pathogenic processes underlying disturbed excitability leading to seizures, in particular in focal epileptic syndromes. Targeted 
mutagenesis is therefore relevant to provide in vitro and in vivo experimental models of epilepsy that can then be studied following a logical progression. Once the pathogenicity of a given mutation is established, the aim is to link its functional consequences to network hyperexcitability. In this review, we detailed the contribution of cellular and animal models to the understanding of two monogenic focal epilepsies, ADNFLE and ADEAF. Mutations in ion channel genes encoding nAChRs and KCNT1 lead to a gain-of-function whereas LGI1 mutations cause a complete loss-of-function. Studying impacts of mutations in specific causative genes is crucial to decipher the neurobiology of epilepsy. However, the biological diversity of epilepsy genes is very rapidly growing, raising the question of whether this time-consuming approach should be applied for each new identified gene, even though new genetic engineering technologies hasten the generation of experimental models. One part of the answer resides in the identification of common molecular pathways, which would make the exploration of a given mutation relevant to the global comprehension of an epileptic syndrome. Genetic modifiers add a level of complexity and may explain inter-individual variability of phenotypes. Heterologous expression systems lack this genetic diversity while the genetic background of animal models is still poorly taken into account. Neurons derived from patients' stem cells present a very interesting option to study epilepsy gene mutations in the context of patients' genetic backgrounds.

\section{ACKNOWLEDGEMENTS}

The research is supported by funding from the Fondation Française pour la Recherche sur les Epilepsies, the Agence Nationale de la Recherche (ANR R10193DD) and the program "Investissements d'avenir" ANR-10-IAIHU-06 and the Fondation Française pour la recherche sur I'Epilepsie (FFRE). M.B. is supported by funds from the Ligue Francaise contre l'Epilepsie. We thank Eric Leguern for discussions and advice. 


\section{References}

Anderson MP. Arrested glutamatergic synapse development in human partial epilepsy. Epilepsy currents / American Epilepsy Society, 2010; $10: 153-8$.

Aridon P, Marini C, Di Resta C, Brilli E, De Fusco M, Politi F, Parrini E, Manfredi I, Pisano T, Pruna D, Curia G, Cianchetti C, Pasqualetti M, Becchetti A, Guerrini $R$, Casari G. Increased sensitivity of the neuronal nicotinic receptor alpha 2 subunit causes familial epilepsy with nocturnal wandering and ictal fear. American journal of human genetics, 2006; 79: 342-50.

Barcia G, Fleming MR, Deligniere A, Gazula VR, Brown MR, Langouet M, Chen H, Kronengold J, Abhyankar A, Cilio R, Nitschke P, Kaminska A, Boddaert N, Casanova JL, Desguerre I, Munnich A, Dulac O, Kaczmarek LK, Colleaux L, Nabbout R. De novo gain-of-function KCNT1 channel mutations cause malignant migrating partial seizures of infancy. Nature genetics, 2012; 44: 1255-9.

Baulac S. Genetics advances in autosomal dominant focal epilepsies: focus on DEPDC5. Progress in brain research, 2014; 213: $123-39$.

Baulac S, Ishida S, Marsan E, Miquel C, Biraben A, Nguyen DK, Nordli D, Cossette P, Nguyen S, Lambrecq V, Vlaicu M, Daniau M, Bielle F, Andermann E, Andermann F, Leguern E, Chassoux F, Picard F. Familial focal epilepsy with focal cortical dysplasia due to DEPDC5 mutations. Ann Neurol, 2015.

Baulac S, Ishida S, Mashimo T, Boillot M, Fumoto N, Kuwamura M, Ohno Y, Takizawa A, Aoto T, Ueda M, Ikeda A, LeGuern E, Takahashi R, Serikawa T. A rat model for LGI1-related epilepsies. Hum Mol Genet, 2012; 21: 3546-57.

Bearden D, Strong A, Ehnot J, DiGiovine M, Dlugos D, Goldberg EM. Targeted treatment of migrating partial seizures of infancy with quinidine. Ann Neurol, 2014; 76: 457-61.

Berghuis B, Brilstra EH, Lindhout D, Baulac S, de Haan GJ, van Kempen M. Hyperactive behavior in a family with autosomal dominant lateral temporal lobe epilepsy caused by a mutation in the LGI1/epitempin gene. Epilepsy \& behavior : E\&B, 2013; 28: 41-6.

Berkovic SF, Izzillo P, McMahon JM, Harkin LA, McIntosh AM, Phillips HA, Briellmann RS, Wallace RH, Mazarib A, Neufeld MY, Korczyn AD, Scheffer IE, Mulley JC. LGI1 mutations in temporal lobe epilepsies. Neurology, 2004; 62: 1115-9.

Bertrand D, Elmslie F, Hughes E, Trounce J, Sander T, Bertrand S, Steinlein OK. The CHRNB2 mutation I312M is associated with epilepsy and distinct memory deficits. Neurobiol Dis, 2005; 20: 799-804.

Bertrand D, Picard F, Le Hellard S, Weiland S, Favre I, Phillips H, Bertrand S, Berkovic SF, Malafosse A, Mulley J. How mutations in the nAChRs can cause ADNFLE epilepsy. Epilepsia, 2002; 43 Suppl 5: 112-22.

Bertrand S, Weiland S, Berkovic SF, Steinlein OK, Bertrand D. Properties of neuronal nicotinic acetylcholine receptor mutants from humans suffering from autosomal dominant nocturnal frontal lobe epilepsy. British journal of pharmacology, 1998; 125: 751-60.

Bisulli F, Tinuper P, Avoni P, Striano P, Striano S, d'Orsi G, Vignatelli L, Bagattin A, Scudellaro E, Florindo I, Nobile C, Tassinari CA, Baruzzi A, Michelucci R. Idiopathic partial epilepsy with auditory features (IPEAF): a clinical and genetic study of 53 sporadic cases. Brain, 2004; 127: $1343-52$. 
Blockus $\mathrm{H}$, Chedotal A. The multifaceted roles of Slits and Robos in cortical circuits: from proliferation to axon guidance and neurological diseases. Current opinion in neurobiology, 2014; 27: 82-8.

Boillot M, Huneau C, Marsan E, Lehongre K, Navarro V, Ishida S, Dufresnois B, Ozkaynak E, Garrigue J, Miles R, Martin B, Leguern E, Anderson MP, Baulac S. Glutamatergic neuron-targeted loss of LGI1 epilepsy gene results in seizures. Brain, 2014; 137: 2984-96.

Chabrol E, Navarro V, Provenzano G, Cohen I, Dinocourt C, Rivaud-Pechoux S, Fricker D, Baulac M, Miles R, Leguern E, Baulac S. Electroclinical characterization of epileptic seizures in leucine-rich, glioma-inactivated 1-deficient mice. Brain, 2010; 133: 2749-62.

Chabrol E, Popescu C, Gourfinkel-An I, Trouillard O, Depienne C, Senechal K, Baulac M, LeGuern E, Baulac S. Two novel epilepsy-linked mutations leading to a loss of function of LGI1. Archives of neurology, 2007; 64: 217-22.

Chen C, Westenbroek RE, Xu X, Edwards CA, Sorenson DR, Chen Y, McEwen DP, O'Malley HA, Bharucha V, Meadows LS, Knudsen GA, Vilaythong A, Noebels $\mathrm{JL}$, Saunders TL, Scheuer T, Shrager P, Catterall WA, Isom LL. Mice lacking sodium channel beta1 subunits display defects in neuronal excitability, sodium channel expression, and nodal architecture. J Neurosci, 2004; 24: 4030-42.

Chen Y, Wu L, Fang Y, He Z, Peng B, Shen Y, Xu Q. A novel mutation of the nicotinic acetylcholine receptor gene CHRNA4 in sporadic nocturnal frontal lobe epilepsy. Epilepsy research, 2009; 83: 152-6.

Chernova OB, Somerville RP, Cowell JK. A novel gene, LGI1, from 10q24 is rearranged and downregulated in malignant brain tumors. Oncogene, 1998; 17: 2873-81.

Cho YW, Motamedi GK, Laufenberg I, Sohn SI, Lim JG, Lee H, Yi SD, Lee JH, Kim DK, Reba R, Gaillard WD, Theodore WH, Lesser RP, Steinlein OK. A Korean kindred with autosomal dominant nocturnal frontal lobe epilepsy and mental retardation. Archives of neurology, 2003; 60: 1625-32.

Cho YW, Yi SD, Lim JG, Kim DK, Motamedi GK. Autosomal dominant nocturnal frontal lobe epilepsy and mild memory impairment associated with CHRNB2 mutation I312M in the neuronal nicotinic acetylcholine receptor. Epilepsy \& behavior : E\&B, 2008; 13: 361-5.

Combi R, Dalpra L, Tenchini ML, Ferini-Strambi L. Autosomal dominant nocturnal frontal lobe epilepsy--a critical overview. Journal of neurology, 2004; 251 : 923-34.

Conti V, Aracri P, Chiti L, Brusco S, Mari F, Marini C, Albanese M, Marchi A, Liguori C, Placidi F, Romigi A, Becchetti A, Guerrini R. Nocturnal frontal lobe epilepsy with paroxysmal arousals due to CHRNA2 loss of function. Neurology, 2015.

Dani JA, Bertrand D. Nicotinic acetylcholine receptors and nicotinic cholinergic mechanisms of the central nervous system. Annual review of pharmacology and toxicology, 2007; 47: 699-729.

Dazzo E, Santulli L, Posar A, Fattouch J, Conti S, Loden-van Straaten M, Mijalkovic J, De Bortoli M, Rosa M, Millino C, Pacchioni B, Di Bonaventura C, Giallonardo AT, Striano S, Striano P, Parmeggiani A, Nobile C. Autosomal dominant lateral temporal epilepsy (ADLTE): novel structural and singlenucleotide LGI1 mutations in families with predominant visual auras. Epilepsy research, 2015; 110: 132-8. 
de Bellescize J, Boutry N, Chabrol E, Andre-Obadia N, Arzimanoglou A, Leguern E, Baulac S, Calender A, Ryvlin P, Lesca G. A novel three base-pair LGI1 deletion leading to loss of function in a family with autosomal dominant lateral temporal epilepsy and migraine-like episodes. Epilepsy research, 2009; 85: $118-22$.

De Fusco M, Becchetti A, Patrignani A, Annesi G, Gambardella A, Quattrone A, Ballabio A, Wanke E, Casari G. The nicotinic receptor beta 2 subunit is mutant in nocturnal frontal lobe epilepsy. Nature genetics, 2000; 26: 275-6.

Di Bonaventura C, Carni M, Diani E, Fattouch J, Vaudano EA, Egeo G, Pantano P, Maraviglia B, Bozzao L, Manfredi M, Prencipe M, Giallonardo TA, Nobile C. Drug resistant ADLTE and recurrent partial status epilepticus with dysphasic features in a family with a novel LGI1 mutation: electroclinical, genetic, and EEG/fMRI findings. Epilepsia, 2009; 50: 2481-6.

Di Bonaventura C, Operto FF, Busolin G, Egeo G, D'Aniello A, Vitello L, Smaniotto G, Furlan S, Diani E, Michelucci R, Giallonardo AT, Coppola G, Nobile C. Low penetrance and effect on protein secretion of LGI1 mutations causing autosomal dominant lateral temporal epilepsy. Epilepsia, $2011 ; 52: 1258-64$.

Diaz-Otero F, Quesada M, Morales-Corraliza J, Martinez-Parra C, Gomez-Garre P, Serratosa JM. Autosomal dominant nocturnal frontal lobe epilepsy with a mutation in the CHRNB2 gene. Epilepsia, 2008; 49: 516-20.

Dibbens LM, de Vries B, Donatello S, Heron SE, Hodgson BL, Chintawar S, Crompton DE, Hughes JN, Bellows ST, Klein KM, Callenbach PM, Corbett MA, Gardner AE, Kivity S, lona X, Regan BM, Weller CM, Crimmins D, O'Brien TJ, Guerrero-Lopez R, Mulley JC, Dubeau F, Licchetta L, Bisulli F, Cossette P, Thomas PQ, Gecz J, Serratosa J, Brouwer OF, Andermann F, Andermann E, van den Maagdenberg AM, Pandolfo M, Berkovic SF, Scheffer IE. Mutations in DEPDC5 cause familial focal epilepsy with variable foci. Nature genetics, 2013; 45: 546-51.

Fanciulli M, Santulli L, Errichiello L, Barozzi C, Tomasi L, Rigon L, Cubeddu T, de Falco A, Rampazzo A, Michelucci R, Uzzau S, Striano S, de Falco FA, Striano P, Nobile C. LGI1 microdeletion in autosomal dominant lateral temporal epilepsy. Neurology, 2012; 78: $1299-303$.

Fertig E, Lincoln A, Martinuzzi A, Mattson RH, Hisama FM. Novel LGI1 mutation in a family with autosomal dominant partial epilepsy with auditory features. Neurology, 2003; 60: 1687-90.

Figl A, Viseshakul N, Shafaee N, Forsayeth J, Cohen BN. Two mutations linked to nocturnal frontal lobe epilepsy cause use-dependent potentiation of the nicotinic ACh response. The Journal of physiology, 1998; 513 ( Pt 3): 655-70.

Fonck C, Cohen BN, Nashmi R, Whiteaker P, Wagenaar DA, Rodrigues-Pinguet N, Deshpande P, McKinney S, Kwoh S, Munoz J, Labarca C, Collins AC, Marks MJ, Lester HA. Novel seizure phenotype and sleep disruptions in knock-in mice with hypersensitive alpha 4* nicotinic receptors. J Neurosci, 2005; 25: 11396-411.

Fukata Y, Adesnik H, Iwanaga T, Bredt DS, Nicoll RA, Fukata M. Epilepsy-related ligand/receptor complex LGI1 and ADAM22 regulate synaptic transmission. Science, 2006; 313: 1792-5. 
Fukata Y, Lovero KL, Iwanaga T, Watanabe A, Yokoi N, Tabuchi K, Shigemoto R, Nicoll RA, Fukata M. Disruption of LGI1-linked synaptic complex causes abnormal synaptic transmission and epilepsy. Proceedings of the National Academy of Sciences of the United States of America, 2010; 107: 3799-804.

Grone BP, Baraban SC. Animal models in epilepsy research: legacies and new directions. Nature neuroscience, 2015; 18: 339-43.

Gu W, Brodtkorb E, Steinlein OK. LGI1 is mutated in familial temporal lobe epilepsy characterized by aphasic seizures. Ann Neurol, 2002; 52: 364-7.

Gullo F, Manfredi I, Lecchi M, Casari G, Wanke E, Becchetti A. Multi-electrode array study of neuronal cultures expressing nicotinic beta2-V287L subunits, linked to autosomal dominant nocturnal frontal lobe epilepsy. An in vitro model of spontaneous epilepsy. Frontiers in neural circuits, $2014 ; 8: 87$.

Hedera P, Abou-Khalil B, Crunk AE, Taylor KA, Haines JL, Sutcliffe JS. Autosomal dominant lateral temporal epilepsy: two families with novel mutations in the LGI1 gene. Epilepsia, 2004; 45: 218-22.

Heiman GA, Kamberakis K, Gill R, Kalachikov S, Pedley TA, Hauser WA, Ottman R. Evaluation of depression risk in LGI1 mutation carriers. Epilepsia, 2010; 51: 1685-90.

Heron SE, Smith KR, Bahlo M, Nobili L, Kahana E, Licchetta L, Oliver KL, Mazarib A, Afawi Z, Korczyn A, Plazzi G, Petrou S, Berkovic SF, Scheffer IE, Dibbens LM. Missense mutations in the sodium-gated potassium channel gene KCNT1 cause severe autosomal dominant nocturnal frontal lobe epilepsy. Nature genetics, 2012; 44: 1188-90.

Hoda JC, Gu W, Friedli M, Phillips HA, Bertrand S, Antonarakis SE, Goudie D, Roberts R, Scheffer IE, Marini C, Patel J, Berkovic SF, Mulley JC, Steinlein OK, Bertrand D. Human nocturnal frontal lobe epilepsy: pharmocogenomic profiles of pathogenic nicotinic acetylcholine receptor beta-subunit mutations outside the ion channel pore. Molecular pharmacology, 2008; 74: 379-91.

Irani SR, Alexander S, Waters P, Kleopa KA, Pettingill P, Zuliani L, Peles E, Buckley C, Lang B, Vincent A. Antibodies to Kv1 potassium channel-complex proteins leucine-rich, glioma inactivated 1 protein and contactin-associated protein-2 in limbic encephalitis, Morvan's syndrome and acquired neuromyotonia. Brain, 2010; 133: 2734-48.

Ishida S, Picard F, Rudolf G, Noe E, Achaz G, Thomas P, Genton P, Mundwiller E, Wolff M, Marescaux C, Miles R, Baulac M, Hirsch E, Leguern E, Baulac S. Mutations of DEPDC5 cause autosomal dominant focal epilepsies. Nature genetics, 2013; 45: 552-5.

Kalachikov S, Evgrafov O, Ross B, Winawer M, Barker-Cummings C, Martinelli Boneschi F, Choi C, Morozov P, Das K, Teplitskaya E, Yu A, Cayanis E, Penchaszadeh G, Kottmann AH, Pedley TA, Hauser WA, Ottman R, Gilliam TC. Mutations in LGI1 cause autosomal-dominant partial epilepsy with auditory features. Nature genetics, 2002; 30: 335-41.

Kawamata J, Ikeda A, Fujita Y, Usui K, Shimohama S, Takahashi R. Mutations in LGI1 gene in Japanese families with autosomal dominant lateral temporal lobe epilepsy: The first report from Asian families. Epilepsia, 2009.

Kegel L, Aunin E, Meijer D, Bermingham JR. LGI proteins in the nervous system. ASN neuro, 2013; 5: 167-81. 
Kim E, Niethammer M, Rothschild A, Jan YN, Sheng M. Clustering of Shaker-type K+ channels by interaction with a family of membrane-associated guanylate kinases. Nature, 1995; 378: 85-8.

Kim GE, Kronengold J, Barcia G, Quraishi IH, Martin HC, Blair E, Taylor JC, Dulac O, Colleaux L, Nabbout R, Kaczmarek LK. Human slack potassium channel mutations increase positive cooperativity between individual channels. Cell reports, 2014; 9: 1661-72.

Klaassen A, Glykys J, Maguire J, Labarca C, Mody I, Boulter J. Seizures and enhanced cortical GABAergic inhibition in two mouse models of human autosomal dominant nocturnal frontal lobe epilepsy. Proceedings of the National Academy of Sciences of the United States of America, 2006; 103: 19152-7.

Kobayashi E, Santos NF, Torres FR, Secolin R, Sardinha LA, Lopez-Cendes I, Cendes F. Magnetic resonance imaging abnormalities in familial temporal lobe epilepsy with auditory auras. Archives of neurology, 2003; 60: 1546-51.

Krex D, Hauses M, Appelt H, Mohr B, Ehninger G, Schackert HK, Schackert G. Physical and functional characterization of the human LGI1 gene and its possible role in glioma development. Acta neuropathologica, 2002; 103: 255-66.

Kuryatov A, Gerzanich V, Nelson M, Olale F, Lindstrom J. Mutation causing autosomal dominant nocturnal frontal lobe epilepsy alters Ca2+ permeability, conductance, and gating of human alpha4beta2 nicotinic acetylcholine receptors. J Neurosci, 1997; 17: 9035-47.

Lai M, Huijbers MGM, Lancaster E, Graus F, Bataller L, Balice-Gordon R, Cowell JK, Dalmau J. Investigation of LGI1 as the antigen in limbic encephalitis previously attributed to potassium channels: a case series. Lancet Neurol, 2010; 9: 776-85.

Lee MK, Kim SW, Lee JH, Cho YJ, Kim DE, Lee BI, Kim HM, Lee MG, Heo K. A newly discovered LGI1 mutation in Korean family with autosomal dominant lateral temporal lobe epilepsy. Seizure : the journal of the British Epilepsy Association, 2013; 23: 69-73.

Leniger T, Kananura C, Hufnagel A, Bertrand S, Bertrand D, Steinlein OK. A new Chrna4 mutation with low penetrance in nocturnal frontal lobe epilepsy. Epilepsia, 2003; 44: 981-5.

Leonardi E, Andreazza S, Vanin S, Busolin G, Nobile C, Tosatto SCE. A Computational Model of the LGI1 Protein Suggests a Common Binding Site for ADAM Proteins. PLoS One, 2011; 6: e18142.

Liu H, Lu C, Li Z, Zhou S, Li X, Ji L, Lu Q, Lv R, Wu L, Ma X. The identification of a novel mutation of nicotinic acetylcholine receptor gene CHRNB2 in a Chinese patient: Its possible implication in non-familial nocturnal frontal lobe epilepsy. Epilepsy research, 2011; 95: 94-9.

Lotfipour S, Byun JS, Leach P, Fowler CD, Murphy NP, Kenny PJ, Gould TJ, Boulter J. Targeted deletion of the mouse alpha2 nicotinic acetylcholine receptor subunit gene (Chrna2) potentiates nicotine-modulated behaviors. J Neurosci, 2013; 33: 7728-41.

Manfredi I, Zani AD, Rampoldi L, Pegorini S, Bernascone I, Moretti M, Gotti C, Croci L, Consalez GG, Ferini-Strambi L, Sala M, Pattini L, Casari G. Expression of mutant beta2 nicotinic receptors during development is crucial for epileptogenesis. Hum Mol Genet, 2009; 18: 1075-88.

Marini C, Guerrini R. The role of the nicotinic acetylcholine receptors in sleep-related epilepsy. Biochemical pharmacology, $2007 ; 74: 1308-14$. 
Martin HC, Kim GE, Pagnamenta AT, Murakami Y, Carvill GL, Meyer E, Copley RR, Rimmer A, Barcia G, Fleming MR, Kronengold J, Brown MR, Hudspith KA, Broxholme J, Kanapin A, Cazier JB, Kinoshita T, Nabbout R, Bentley D, McVean G, Heavin S, Zaiwalla Z, McShane T, Mefford HC, Shears D, Stewart H, Kurian MA, Scheffer IE, Blair E, Donnelly P, Kaczmarek LK, Taylor JC. Clinical whole-genome sequencing in severe early-onset epilepsy reveals new genes and improves molecular diagnosis. Hum Mol Genet, 2014; 23: 3200-11.

McLellan A, Phillips HA, Rittey C, Kirkpatrick M, Mulley JC, Goudie D, Stephenson JB, Tolmie J, Scheffer IE, Berkovic SF, Zuberi SM. Phenotypic comparison of two Scottish families with mutations in different genes causing autosomal dominant nocturnal frontal lobe epilepsy. Epilepsia, $2003 ; 44: 613-7$.

Michelucci R, Mecarelli O, Bovo G, Bisulli F, Testoni S, Striano P, Striano S, Tinuper P, Nobile C. A de novo LGI1 mutation causing idiopathic partial epilepsy with telephone-induced seizures. Neurology, 2007; 68: 2150-1.

Michelucci R, Pasini E, Nobile C. Lateral temporal lobe epilepsies: clinical and genetic features. Epilepsia, 2009; 50 Suppl 5: 52-4.

Michelucci R, Poza JJ, Sofia V, de Feo MR, Binelli S, Bisulli F, Scudellaro E, Simionati B, Zimbello R, D'Orsi G, Passarelli D, Avoni P, Avanzini G, Tinuper P, Biondi R, Valle G, Mautner VF, Stephani U, Tassinari CA, Moschonas NK, Siebert R, Lopez de Munain A, Perez-Tur J, Nobile C. Autosomal dominant lateral temporal epilepsy: clinical spectrum, new epitempin mutations, and genetic heterogeneity in seven European families. Epilepsia, $2003 ; 44: 1289-97$.

Milligan CJ, Li M, Gazina EV, Heron SE, Nair U, Trager C, Reid CA, Venkat A, Younkin DP, Dlugos DJ, Petrovski S, Goldstein DB, Dibbens LM, Scheffer IE, Berkovic SF, Petrou S. KCNT1 gain of function in 2 epilepsy phenotypes is reversed by quinidine. Ann Neurol, 2014; 75: 581-90.

Mitchell KJ, Pinson KI, Kelly OG, Brennan J, Zupicich J, Scherz P, Leighton PA, Goodrich LV, Lu X, Avery BJ, Tate P, Dill K, Pangilinan E, Wakenight P, TessierLavigne M, Skarnes WC. Functional analysis of secreted and transmembrane proteins critical to mouse development. Nature genetics, 2001; 28: 241-9.

Morante-Redolat JM, Gorostidi-Pagola A, Piquer-Sirerol S, Saenz A, Poza JJ, Galan J, Gesk S, Sarafidou T, Mautner VF, Binelli S, Staub E, Hinzmann B, French L, Prud'homme JF, Passarelli D, Scannapieco P, Tassinari CA, Avanzini G, Marti-Masso JF, Kluwe L, Deloukas P, Moschonas NK, Michelucci R, Siebert R, Nobile C, Perez-Tur J, Lopez de Munain A. Mutations in the LGI1/Epitempin gene on 10q24 cause autosomal dominant lateral temporal epilepsy. Hum Mol Genet, 2002; 11: 1119-28.

Nobile C, Michelucci R, Andreazza S, Pasini E, Tosatto SC, Striano P. LGI1 mutations in autosomal dominant and sporadic lateral temporal epilepsy. Human mutation, 2009; 30: 530-6.

O'Neill HC, Laverty DC, Patzlaff NE, Cohen BN, Fonck C, McKinney S, McIntosh JM, Lindstrom JM, Lester HA, Grady SR, Marks MJ. Mice expressing the ADNFLE valine 287 leucine mutation of the Beta2 nicotinic acetylcholine receptor subunit display increased sensitivity to acute nicotine administration and altered presynaptic nicotinic receptor function. Pharmacology, biochemistry, and behavior, 2013; 103: 603-21.

Ogawa Y, Oses-Prieto J, Kim MY, Horresh I, Peles E, Burlingame AL, Trimmer JS, Meijer D, Rasband MN. ADAM22, a Kv1 channel-interacting protein, recruits membrane-associated guanylate kinases to juxtaparanodes of myelinated axons. J Neurosci, 2010; 30: 1038-48. 
Ohkawa T, Fukata Y, Yamasaki M, Miyazaki T, Yokoi N, Takashima H, Watanabe M, Watanabe O, Fukata M. Autoantibodies to Epilepsy-Related LGI1 in Limbic Encephalitis Neutralize LGI1-ADAM22 Interaction and Reduce Synaptic AMPA Receptors. J Neurosci, 2013; 33: 18161-74.

Ottman R, Winawer MR, Kalachikov S, Barker-Cummings C, Gilliam TC, Pedley TA, Hauser WA. LGI1 mutations in autosomal dominant partial epilepsy with auditory features. Neurology, 2004; 62: 1120-6.

Owuor K, Harel NY, Englot DJ, Hisama F, Blumenfeld H, Strittmatter SM. LGI1-associated epilepsy through altered ADAM23-dependent neuronal morphology. Molecular and cellular neurosciences, 2009; 42: 448-57.

Phillips HA, Favre I, Kirkpatrick M, Zuberi SM, Goudie D, Heron SE, Scheffer IE, Sutherland GR, Berkovic SF, Bertrand D, Mulley JC. CHRNB2 is the second acetylcholine receptor subunit associated with autosomal dominant nocturnal frontal lobe epilepsy. American journal of human genetics, 2001; 68: 22531.

Phillips HA, Marini C, Scheffer IE, Sutherland GR, Mulley JC, Berkovic SF. A de novo mutation in sporadic nocturnal frontal lobe epilepsy. Ann Neurol, 2000; 48: $264-7$

Picard F, Baulac S, Kahane P, Hirsch E, Sebastianelli R, Thomas P, Vigevano F, Genton P, Guerrini R, Gericke CA, An I, Rudolf G, Herman A, Brice A, Marescaux C, LeGuern E. Dominant partial epilepsies. A clinical, electrophysiological and genetic study of 19 European families. Brain, $2000 ; 123$ ( Pt 6): $1247-62$.

Picard F, Makrythanasis P, Navarro V, Ishida S, de Bellescize J, Ville D, Weckhuysen S, Fosselle E, Suls A, De Jonghe P, Vasselon Raina M, Lesca G, Depienne C, An-Gourfinkel I, Vlaicu M, Baulac M, Mundwiller E, Couarch P, Combi R, Ferini-Strambi L, Gambardella A, Antonarakis SE, Leguern E, Steinlein O, Baulac S. DEPDC5 mutations in families presenting as autosomal dominant nocturnal frontal lobe epilepsy. Neurology, 2014; 82: 2101-6.

Picard F, Pegna AJ, Arntsberg V, Lucas N, Kaczmarek I, Todica O, Chiriaco C, Seeck M, Brodtkorb E. Neuropsychological disturbances in frontal lobe epilepsy due to mutated nicotinic receptors. Epilepsy \& behavior : E\&B, 2009; 14: 354-9.

Picard F, Scheffer IE. Genetically determined focal epilepsies In M. Bureau PG, C. Dravet, A.V. Delgado-Escueta, C.A. Tassinari, P. Thomas, P.Wolf, editor. Epileptic Syndromes in Infancy, Childhood and Adolescence Montrouge: John Libbey Eurotext 2012: 349-61.

Picciotto MR, Zoli M, Lena C, Bessis A, Lallemand Y, Le Novere N, Vincent P, Pich EM, Brulet P, Changeux JP. Abnormal avoidance learning in mice lacking functional high-affinity nicotine receptor in the brain. Nature, 1995; 374: 65-7.

Pisano T, Marini C, Brovedani P, Brizzolara D, Pruna D, Mei D, Moro F, Cianchetti C, Guerrini R. Abnormal phonologic processing in familial lateral temporal lobe epilepsy due to a new LGI1 mutation. Epilepsia, 2005; 46: 118-23.

Pizzuti A, Flex E, Di Bonaventura C, Dottorini T, Egeo G, Manfredi M, Dallapiccola B, Giallonardo AT. Epilepsy with auditory features: A LGI1 gene mutation suggests a loss-of-function mechanism. Ann Neurol, 2003; 53: 396-9.

Rodrigues-Pinguet N, Jia L, Li M, Figl A, Klaassen A, Truong A, Lester HA, Cohen BN. Five ADNFLE mutations reduce the Ca2+ dependence of the mammalian alpha4beta2 acetylcholine response. The Journal of physiology, 2003; 550: 11-26. 
Rosanoff MJ, Ottman R. Penetrance of LGI1 mutations in autosomal dominant partial epilepsy with auditory features. Neurology, 2008; 71: 567-71.

Ross SA, Wong JY, Clifford JJ, Kinsella A, Massalas JS, Horne MK, Scheffer IE, Kola I, Waddington JL, Berkovic SF, Drago J. Phenotypic characterization of an alpha 4 neuronal nicotinic acetylcholine receptor subunit knock-out mouse. J Neurosci, 2000; 20: 6431-41.

Rozycka A, Skorupska E, Kostyrko A, Trzeciak WH. Evidence for S284L mutation of the CHRNA4 in a white family with autosomal dominant nocturnal frontal lobe epilepsy. Epilepsia, 2003; 44: 1113-7.

Sadleir LG, Agher D, Chabrol E, Elkouby L, Leguern E, Paterson SJ, Harty R, Bellows ST, Berkovic SF, Scheffer IE, Baulac S. Seizure semiology in autosomal dominant epilepsy with auditory features, due to novel LGI1 mutations. Epilepsy research, 2013; 107: 311-7.

Saenz A, Galan J, Caloustian C, Lorenzo F, Marquez C, Rodriguez N, Jimenez MD, Poza JJ, Cobo AM, Grid D, Prud'homme JF, Lopez de Munain A. Autosomal dominant nocturnal frontal lobe epilepsy in a Spanish family with a Ser252Phe mutation in the CHRNA4 gene. Archives of neurology, $1999 ; 56: 1004-9$.

Sagane K, Ishihama Y, Sugimoto H. LGI1 and LGI4 bind to ADAM22, ADAM23 and ADAM11. International journal of biological sciences, 2008; 4: 387-96.

Sansoni V, Forcella M, Mozzi A, Fusi P, Ambrosini R, Ferini-Strambi L, Combi R. Functional characterization of a CRH missense mutation identified in an ADNFLE family. PLoS One, 2013; 8: e61306.

Sansoni V, Nobili L, Proserpio P, Ferini-Strambi L, Combi R. A de novo mutation in an Italian sporadic patient affected by nocturnal frontal lobe epilepsy. Journal of sleep research, 2012; 21: 352-3.

Scheel H, Tomiuk S, Hofmann K. A common protein interaction domain links two recently identified epilepsy genes. Hum Mol Genet, $2002 ; 11: 1757-62$.

Schulte U, Thumfart JO, Klocker N, Sailer CA, BildI W, Biniossek M, Dehn D, Deller T, Eble S, Abbass K, Wangler T, Knaus HG, Fakler B. The epilepsy-linked Lgi1 protein assembles into presynaptic Kv1 channels and inhibits inactivation by Kvbeta1. Neuron, 2006; 49: 697-706.

Senechal KR, Thaller C, Noebels JL. ADPEAF mutations reduce levels of secreted LGI1, a putative tumor suppressor protein linked to epilepsy. Hum Mol Genet, 2005; 14: 1613-20.

Sirerol-Piquer MS, Ayerdi-Izquierdo A, Morante-Redolat JM, Herranz-Perez V, Favell K, Barker PA, Perez-Tur J. The epilepsy gene LGI1 encodes a secreted glycoprotein that binds to the cell surface. Hum Mol Genet, 2006; 15: 3436-45.

Smart SL, Lopantsev V, Zhang CL, Robbins CA, Wang H, Chiu SY, Schwartzkroin PA, Messing A, Tempel BL. Deletion of the K(V)1.1 potassium channel causes epilepsy in mice. Neuron, 1998; 20: 809-19.

Staub E, Perez-Tur J, Siebert R, Nobile C, Moschonas NK, Deloukas P, Hinzmann B. The novel EPTP repeat defines a superfamily of proteins implicated in epileptic disorders. Trends Biochem Sci, 2002; 27: 441-4.

Steinlein OK. Animal models for autosomal dominant frontal lobe epilepsy: on the origin of seizures. Expert review of neurotherapeutics, $2010 ; 10: 1859-67$.

Steinlein OK. Genetic heterogeneity in familial nocturnal frontal lobe epilepsy. Progress in brain research, 2014; 213: 1-15. 
Steinlein OK, Magnusson A, Stoodt J, Bertrand S, Weiland S, Berkovic SF, Nakken KO, Propping P, Bertrand D. An insertion mutation of the CHRNA4 gene in a family with autosomal dominant nocturnal frontal lobe epilepsy. Hum Mol Genet, 1997; 6: 943-7.

Steinlein OK, Mulley JC, Propping P, Wallace RH, Phillips HA, Sutherland GR, Scheffer IE, Berkovic SF. A missense mutation in the neuronal nicotinic acetylcholine receptor alpha 4 subunit is associated with autosomal dominant nocturnal frontal lobe epilepsy. Nature genetics, $1995 ; 11: 201-3$.

Steinlein OK, Stoodt J, Mulley J, Berkovic S, Scheffer IE, Brodtkorb E. Independent occurrence of the CHRNA4 Ser248Phe mutation in a Norwegian family with nocturnal frontal lobe epilepsy. Epilepsia, 2000; 41: 529-35.

Striano P, Busolin G, Santulli L, Leonardi E, Coppola A, Vitiello L, Rigon L, Michelucci R, Tosatto SCE, Striano S, Nobile C. Familial temporal lobe epilepsy with psychic auras associated with a novel LGI1 mutation. Neurology, 2011; 76: 1173-6.

Striano P, de Falco A, Diani E, Bovo G, Furlan S, Vitiello L, Pinardi F, Striano S, Michelucci R, de Falco FA, Nobile C. A novel loss-of-function LGI1 mutation linked to autosomal dominant lateral temporal epilepsy. Archives of neurology, 2008; 65: 939-42.

Tan HO, Reid CA, Single FN, Davies PJ, Chiu C, Murphy S, Clarke AL, Dibbens L, Krestel H, Mulley JC, Jones MV, Seeburg PH, Sakmann B, Berkovic SF, Sprengel $\mathrm{R}$, Petrou S. Reduced cortical inhibition in a mouse model of familial childhood absence epilepsy. Proceedings of the National Academy of Sciences of the United States of America, 2007; 104: 17536-41.

Teng Y, Xie X, Walker S, Rempala G, Kozlowski DJ, Mumm JS, Cowell JK. Knockdown of zebrafish Lgi1a results in abnormal development, brain defects and a seizure-like behavioral phenotype. Hum Mol Genet, 2010; 19: 4409-20.

Teng Y, Xie X, Walker S, Saxena M, Kozlowski DJ, Mumm JS, Cowell JK. Loss of zebrafish Igi1b leads to hydrocephalus and sensitization to pentylenetetrazol induced seizure-like behavior. PLoS One, 2011; 6: e24596.

Teper Y, Whyte D, Cahir E, Lester HA, Grady SR, Marks MJ, Cohen BN, Fonck C, McClure-Begley T, Mclntosh JM, Labarca C, Lawrence A, Chen F, Gantois I, Davies PJ, Petrou S, Murphy M, Waddington J, Horne MK, Berkovic SF, Drago J. Nicotine-induced dystonic arousal complex in a mouse line harboring a human autosomal-dominant nocturnal frontal lobe epilepsy mutation. J Neurosci, 2007; 27: 10128-42.

Thomas R, Favell K, Morante-Redolat J, Pool M, Kent C, Wright M, Daignault K, Ferraro GB, Montcalm S, Durocher Y, Fournier A, Perez-Tur J, Barker PA. LGI1 is a Nogo receptor 1 ligand that antagonizes myelin-based growth inhibition. J Neurosci, 2010; 30: 6607-12.

Wang MY, Liu XZ, Wang J, Wu LW. A novel mutation of the nicotinic acetylcholine receptor gene CHRNA4 in a Chinese patient with non-familial nocturnal frontal lobe epilepsy. Epilepsy research, 2014; 108: 1927-31.

Weiland S, Witzemann V, Villarroel A, Propping P, Steinlein O. An amino acid exchange in the second transmembrane segment of a neuronal nicotinic receptor causes partial epilepsy by altering its desensitization kinetics. FEBS letters, 1996; 398: 91-6.

Winawer MR, Ottman R, Hauser WA, Pedley TA. Autosomal dominant partial epilepsy with auditory features: defining the phenotype. Neurology, 2000; 54: 2173-6. 
Xu J, Cohen BN, Zhu Y, Dziewczapolski G, Panda S, Lester HA, Heinemann SF, Contractor A. Altered activity-rest patterns in mice with a human autosomaldominant nocturnal frontal lobe epilepsy mutation in the beta2 nicotinic receptor. Molecular psychiatry, 2011; 16: 1048-61.

Yamada J, Zhu G, Okada M, Hirose S, Yoshida S, Shiba Y, Migita K, Mori F, Sugawara T, Chen L, Liu F, Yoshida S, Ueno S, Kaneko S. A novel prophylactic effect of furosemide treatment on autosomal dominant nocturnal frontal lobe epilepsy (ADNFLE). Epilepsy research, 2013; 107: 127-37.

Yokoi N, Fukata Y, Kase D, Miyazaki T, Jaegle M, Ohkawa T, Takahashi N, Iwanari H, Mochizuki Y, Hamakubo T, Imoto K, Meijer D, Watanabe M, Fukata M. Chemical corrector treatment ameliorates increased seizure susceptibility in a mouse model of familial epilepsy. Nature medicine, 2015; $21: 19-26$.

Yu FH, Mantegazza M, Westenbroek RE, Robbins CA, Kalume F, Burton KA, Spain WJ, McKnight GS, Scheuer T, Catterall WA. Reduced sodium current in GABAergic interneurons in a mouse model of severe myoclonic epilepsy in infancy. Nature neuroscience, 2006; 9: 1142-9.

Yu YE, Wen L, Silva J, Li Z, Head K, Sossey-Alaoui K, Pao A, Mei L, Cowell JK. Lgi1 null mutant mice exhibit myoclonic seizures and CA1 neuronal hyperexcitability. Hum Mol Genet, 2010; 19: 1702-11.

Zhou YD, Lee S, Jin Z, Wright M, Smith SE, Anderson MP. Arrested maturation of excitatory synapses in autosomal dominant lateral temporal lobe epilepsy. Nature medicine, 2009; 15: 1208-14.

Zhou YD, Zhang D, Ozkaynak E, Wang X, Kasper EM, Leguern E, Baulac S, Anderson MP. Epilepsy Gene LGI1 Regulates Postnatal Developmental Remodeling of Retinogeniculate Synapses. J Neurosci, 2012; 32: 903-10.

Zhu G, Okada M, Yoshida S, Ueno S, Mori F, Takahara T, Saito R, Miura Y, Kishi A, Tomiyama M, Sato A, Kojima T, Fukuma G, Wakabayashi K, Hase K, Ohno H, Kijima H, Takano Y, Mitsudome A, Kaneko S, Hirose S. Rats harboring S284L Chrna4 mutation show attenuation of synaptic and extrasynaptic GABAergic transmission and exhibit the nocturnal frontal lobe epilepsy phenotype. J Neurosci, 2008; 28: 12465-76. 


\begin{tabular}{|c|c|c|c|c|c|c|c|c|}
\hline Gene & Mutation & Location & References & Models & $\begin{array}{l}\text { Coexpressed } \\
\text { subunit }\end{array}$ & Main effect on AChR properties & Pathomechanism & References \\
\hline \multirow{7}{*}{ CHRNA4 } & 1275F & TM2 & (Wang et al., 2014) & Not studied & & 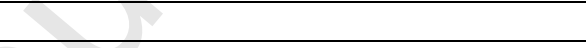 & & \\
\hline & S280F & TM2 & $\begin{array}{l}\text { (Saenz et al., 1999; Steinlein et al., 1995) } \\
\text { (McLellan et al., 2003; Steinlein et al., 2000) }\end{array}$ & Xenopus oocytes & $\beta 2$ & $\begin{array}{l}\text { increased ACh sensitivity and desensitization to ACh, } \\
\text { reduced Ca2+ permeability }\end{array}$ & gain-of-function & (Bertrand et al., 2002) \\
\hline & \multirow[b]{2}{*}{ S284L } & \multirow[b]{2}{*}{ TM2 } & \multirow{2}{*}{$\begin{array}{l}\text { (Cho et al., 2003; Phillips et al., 2000) } \\
\text { (Rozycka et al., 2003; Sansoni et al., 2012) }\end{array}$} & Xenopus oocytes & $\beta 2$ & increased ACh sensitivity & gain-of-function & (Bertrand et al., 2002) \\
\hline & & & & Xenopus oocytes & $\beta 2$ & reduced $\mathrm{Ca} 2+$ dependence of the $\mathrm{ACh}$ response & gain-of-function & $\begin{array}{l}\text { (Rodrigues-Pinguet et } \\
\text { al., 2003) }\end{array}$ \\
\hline & L291dup & TM2 & (Steinlein et al., 1997) & Xenopus oocytes & $\beta 2$ & increased ACh sensitivity, reduced $\mathrm{Ca} 2+$ permeability & gain-of-function & (Bertrand et al., 2002) \\
\hline & T293I & TM2 & (Leniger et al., 2003) & Xenopus oocytes & $\beta 2$ & increased ACh sensitivity & gain-of-function & (Leniger et al., 2003) \\
\hline & $\mathrm{R} 336 \mathrm{H}$ & $\begin{array}{l}\text { second intracellular } \\
\text { domain }\end{array}$ & (Chen et al., 2009) & Not studied & (e. & & & \\
\hline \multirow{7}{*}{ CHRNB2 } & V287L & $\begin{array}{l}\text { second extracellular } \\
\text { domain }\end{array}$ & (De Fusco et al., 2000) & HEK-293T cells & $\alpha 4$ & retardation of channel desensitization & gain-of-function & (De Fusco et al., 2000) \\
\hline & \multirow{2}{*}{ V287M } & \multirow{2}{*}{$\begin{array}{l}\text { second extracellular } \\
\text { domain }\end{array}$} & \multirow{2}{*}{ (Diaz-Otero et al., 2008; Phillips et al., 2001) } & Xenopus oocytes & $\alpha 4$ & increased ACh sensitivity & gain-of-function & $\begin{array}{l}\text { (Phillips et al., 2001) } \\
\text { (Bertrand et al., 2002) }\end{array}$ \\
\hline & & & & Xenopus oocytes & $\beta 2$ & reduced $\mathrm{Ca} 2+$ dependence of the $\mathrm{ACh}$ response & gain-of-function & $\begin{array}{l}\text { (Rodrigues-Pinguet et } \\
\text { al., 2003) }\end{array}$ \\
\hline & L301V & TM3 & (Hoda et al., 2008) & Xenopus oocytes & $\alpha 4$ & increased ACh sensitivity & gain-of-function & (Hoda et al., 2008) \\
\hline & V308A & TM3 & (Hoda et al., 2008) & Xenopus oocytes & $\alpha 4$ & increased ACh sensitivity & gain-of-function & (Hoda et al., 2008) \\
\hline & I312M & TM3 & (Bertrand et al., 2005; Cho et al., 2008) & Xenopus oocytes & $\alpha 4$ & increased ACh sensitivity & gain-of-function & (Bertrand et al., 2005) \\
\hline & V337G & $\begin{array}{l}\text { second intracellular } \\
\text { domain }\end{array}$ & (Liu et al., 2011) & Not studied & & & & \\
\hline \multirow{2}{*}{ CHRNA2 } & $1279 \mathrm{~N}$ & TM1 & (Aridon et al., 2006) & HEK-293T cells & $\beta 4$ & increased nicotine sensitivity & gain-of-function & (Aridon et al., 2006) \\
\hline & $1297 \mathrm{~F}$ & TM2 & (Conti et al., 2015) & HEK-293T cells & $\beta 2$ or $\beta 4$ & reduced nicotine-elicited current density & loss-of-function & (Conti et al., 2015) \\
\hline
\end{tabular}

Table 1: ADNFLE mutations in nicotinic receptor genes and their in vitro impact on nAChR functional properties. 


\begin{tabular}{|c|c|c|c|c|c|c|c|c|}
\hline Gene & Species & Model & Mutation & Genotype & Genetic background & $\begin{array}{l}\text { Epileptic seizu } \\
\text { Spontaneous }\end{array}$ & $\begin{array}{l}\text { es } \\
\text { Nicotine-induced }\end{array}$ & References \\
\hline \multirow{5}{*}{ CHRNA4 } & \multirow{4}{*}{ Mouse } & KO & Null allele & $-1-$ & $\mathrm{BALB} / \mathrm{C}, \mathrm{CF} 1, \mathrm{C} 57 \mathrm{BI} / 6$ & No & No & (Ross et al., 2000) \\
\hline & & $\mathrm{KI}$ & "L9'A" & $+/-$ & $\mathrm{C} 57 \mathrm{BI} / 6$ & No & Yes & (Fonck et al., 2005) \\
\hline & & $\mathrm{KI}$ & S280F & $+/-$ & Not available & Yes & Yes & (Klaassen et al., 2006) \\
\hline & & $\mathrm{KI}$ & S280F & $+/-$ & CD1/129Sv or C57BI/6 & No & Yes & (Teper et al., 2007) \\
\hline & Rat & $\mathrm{OE}$ & S284L & & Sprague Dawley & Yes & Yes & (Zhu et al., 2008) \\
\hline \multirow{3}{*}{ CHRNB2 } & \multirow{3}{*}{ Mouse } & KO & Null allele & $-/-$ & C57BI/6, DBA/2 & No & No & (Picciotto et al., 1995) \\
\hline & & $\mathrm{KI}$ & V287L & $-/-$ & $\mathrm{C} 57 \mathrm{BI} / 6$ & No & Yes & (O'Neill et al., 2013; Xu et al., 2011) \\
\hline & & $\mathrm{OE}$ & V287L & & FVB & Yes & NA & (Manfredi et al., 2009) \\
\hline CHRNA2 & Mouse & KO & Null allele & $-/-$ & $\mathrm{C} 57 \mathrm{BI} / 6$ & No & No & (Lotfipour et al., 2013) \\
\hline
\end{tabular}

Table 2: M urine models of ADNFLE linked to nAChR subunit genes. 


\begin{tabular}{|c|c|c|c|c|c|}
\hline References & Mutation & Exon & Mutation type & Domain & Effect on secretion \\
\hline (Berkovic et al., 2004) & c. $124 \mathrm{~T}>\mathrm{G}$ & 1 & missense & LRR-NT & defective \\
\hline (Ottman et al., 2004) & c. $124 \mathrm{~T}>\mathrm{C}$ & 1 & missense & LRR-NT & defective \\
\hline (Gu et al., 2002; Pizzuti et al., 2003) & c. $136 \mathrm{~T}>\mathrm{C}$ & 1 & missense & LRR-NT & defective \\
\hline (Lee et al., 2013) & c. $137 \mathrm{G}>\mathrm{T}$ & 1 & missense & LRR-NT & defective \\
\hline (Sadleir et al., 2013) & c. $245 \mathrm{~T}>\mathrm{C}$ & 2 & missense & LRR1 & not studied \\
\hline (Ottman et al., 2004) & c. $329 C>A$ & 3 & missense & LRR1 & defective \\
\hline (Striano et al., 2008) & c. $365 \mathrm{~T}>\mathrm{A}$ & 4 & missense & LRR2 & defective \\
\hline (Di Bonaventura et al., 2011) & c. $365 \mathrm{~T}>\mathrm{C}$ & 4 & missense & LRR2 & defective \\
\hline (Di Bonaventura et al., 2009) & c. $367 \mathrm{G}>\mathrm{A}$ & 4 & missense & LRR2 & defective \\
\hline (de Bellescize et al., 2009) & c.377_379del & 4 & missense & LRR2 & defective \\
\hline (Di Bonaventura et al., 2011; Michelucci et al., 2007) & c. $406 C>T$ & 4 & missense & LRR2 & defective \\
\hline (Hedera et al., 2004) & c. $435 \mathrm{C}>\mathrm{G}$ & 5 & missense & LRR3 & defective \\
\hline (Pisano et al., 2005) & c. $461 \mathrm{~T}>\mathrm{C}$ & 5 & missense & LRR3 & defective \\
\hline (Di Bonaventura et al., 2011) & c.535T $>C$ & 6 & missense & LRR-CT & defective \\
\hline (Michelucci et al., 2003) & c.598T>C & 6 & missense & LRR-CT & defective \\
\hline (Chabrol et al., 2007) & c.695T>C & 7 & missense & EPTP1 & defective \\
\hline (Dazzo et al., 2015) & c. $856 \mathrm{~T}>\mathrm{C}$ & 8 & missense & EPTP2 & not studied \\
\hline (Ottman et al., 2004) & c.893T>C & 8 & missense & EPTP2 & defective \\
\hline (Fertig et al., 2003) & c. $953 \mathrm{~T}>\mathrm{G}$ & 8 & missense & EPTP3 & defective \\
\hline (Dazzo et al., 2015) & c. $1118 \mathrm{~T}>\mathrm{C}$ & 8 & missense & EPTP4 & not studied \\
\hline (Leonardi et al., 2011) & c. $1138 \mathrm{~A}>\mathrm{G}$ & 8 & missense & EPTP4 & defective \\
\hline (Kalachikov et al., 2002) & c. $1148 \mathrm{~A}>\mathrm{C}$ & 8 & missense & EPTP4 & defective \\
\hline (Striano et al., 2011) & c. $1219 \mathrm{C}>\mathrm{T}$ & 8 & missense & EPTP4 & competent \\
\hline (Michelucci et al., 2003) & c. $1295 \mathrm{~T}>\mathrm{A}$ & 8 & missense & EPTP5 & defective \\
\hline (Berkovic et al., 2004; Kawamata et al., 2009) & c. $1418 \mathrm{C}>\mathrm{T}$ & 8 & missense & EPTP6 & competent \\
\hline (Kawamata et al., 2009) & c. $1421 \mathrm{G}>\mathrm{A}$ & 8 & missense & EPTP6 & competent \\
\hline (Heiman et al., 2010) & c. $1477 \mathrm{G}>\mathrm{A}$ & 8 & missense & EPTP6 & defective \\
\hline (Dazzo et al., 2015) & microdeletion & 2 & deletion & & \\
\hline (Hedera et al., 2004) & c.329del & 3 & frameshift & & \\
\hline (Kalachikov et al., 2002) & c. $360-3 C>A$ & intron 3 & splice site & & \\
\hline (Berghuis et al., 2013; Chabrol et al., 2007) & c. $431+1 G>A$ & intron 4 & splice site & & \\
\hline (Sadleir et al., 2013) & c.432-2_436del & intron 4 & splice site & & \\
\hline (Fanciulli et al., 2012) & deletion & $1-4$ & deletion & & \\
\hline (Heiman et al., 2010) & c.598del & 6 & frameshift & & \\
\hline (Kalachikov et al., 2002) & c.611del & 6 & frameshift & & \\
\hline (Sadleir et al., 2013) & c. $673 G>T$ & 6 & nonsense & & \\
\hline (Michelucci et al., 2003; Morante-Redolat et al., 2002) & c. $758 \mathrm{del}$ & 7 & frameshift & & \\
\hline (Kobayashi et al., 2003) & c. $839-2 A>G$ & intron 7 & splice site & & \\
\hline (Kalachikov et al., 2002) & c.1050_1051del & 8 & frameshift & & \\
\hline (Bisulli et al., 2004; Morante-Redolat et al., 2002) & c. $1420 \mathrm{C}>\mathrm{T}$ & 8 & nonsense & & \\
\hline (Heiman et al., 2010) & c.1636_1637del & 8 & frameshift & & \\
\hline (Kalachikov et al., 2002) & c.1639dup & 8 & frameshift & & \\
\hline
\end{tabular}


Table 3: ADEAF mutations in LGI1 and impact on secretion of missense mutations. 


\begin{tabular}{|c|c|c|c|c|c|c|c|}
\hline \multirow{2}{*}{ Species } & \multirow{2}{*}{ Model } & \multirow{2}{*}{ Mutation } & \multirow{2}{*}{ Genotype } & \multirow{2}{*}{ Genetic background } & \multicolumn{2}{|c|}{ Epileptic seizures } & \multirow{2}{*}{ References } \\
\hline & & & & & Spontaneous & Induced & \\
\hline \multirow{10}{*}{ Mouse } & $\mathrm{OE}$ & truncated & & $\mathrm{C} 57 \mathrm{BI} / 6$ & No & Yes (PTZ) & (Zhou et al., 2009) \\
\hline & $\mathrm{OE}$ & WT & & C57BI/6 & No & No (PTZ) & (Zhou et al., 2009) \\
\hline & KO & Null allele & $-/-$ & C57BI/6 & Yes & & (Chabrol et al., 2010) \\
\hline & KO & Null allele & $+/-$ & C57BI/6 & No & Yes (sound) & (Chabrol et al., 2010) \\
\hline & КO & Null allele & $-/-$ & C57BI/6 & Yes & & (Fukata et al., 2010) \\
\hline & KO & Null allele & $+/-$ & $\mathrm{C} 57 \mathrm{BI} / 6$ & No & Yes (PTZ) & (Fukata et al., 2010) \\
\hline & KO & Null allele & $-/-$ & albino C57BI/6 & Yes & & (Yu et al., 2010) \\
\hline & cKO & Null allele & Emx1 & C57BI/6 & Yes & & (Boillot et al., 2014) \\
\hline & cKO & Null allele & CaMKII & C57BI/6 & Yes & Not studied & (Boillot et al., 2014) \\
\hline & cKO & Null allele & PV & $\mathrm{C} 57 \mathrm{BI} / 6$ & No & No (PTZ) & (Boillot et al., 2014) \\
\hline \multirow{2}{*}{ Rat } & $\mathrm{KI}$ & L385R & $-/-$ & F344/NSIC & Yes & & (Baulac et al., 2012) \\
\hline & $\mathrm{KI}$ & L385R & $+/-$ & F344/NSlc & No & Yes (sound) & (Baulac et al., 2012) \\
\hline
\end{tabular}

Table 4: M urine models of ADEAF linked to LGI1. 